\title{
Análise da regionalização do saneamento: Cenários hídricos e (in)sustentabilidade econômico-financeira das microrregiões de água e esgoto da Paraíba
}

\author{
Analysis of sanitation regionalization: Water scenarios and economic-financial (in)sustainability of \\ the water and sewage microregions of Paraíba \\ Análisis de la regionalización del saneamiento: Escenarios hídricos y (des) sustentabilidade \\ económico-financiera de las microrregiones de agua y alcantarillado en Paraíba
}

\section{Resumo}

No dia 15 de julho de 2020, foi publicada a Lei Federal $n^{\circ} 14.026$, que altera um conjunto de leis relacionadas ao saneamento. Essa Lei estabeleceu um prazo de um ano para que os Estados criassem uma estrutura de regionalização do saneamento, especificamente dos serviços de água e esgoto. Se os Estados não implantarem as Microrregiões de Água e Esgoto no prazo estabelecido, a regionalização do saneamento, será estabelecida de forma compulsória pela União, com a criação de blocos de referência. A Paraíba, por meio da Lei Complementar nº 168 (2021), criou quatro microrregiões: Alto Piranhas, Borborema, Espinharas e Litoral. Esse artigo tem como objetivo analisar a viabilidade técnica e a sustentabilidade econômico-financeira e ambiental dessas microrregiões. Foram analisados indicadores e informações sobre os municípios paraibanos disponibilizados pelo Sistema Nacional de Informações sobre Saneamento (SNIS), em 2015, 2017 e 2019, como o indicador de desempenho financeiro (IN012) e o índice de suficiência de caix a (IN101), e os diferentes cenários de disponibilidade hídrica, através dos dados de monitoramento dos açudes existentes nessas microrregiões, em 2015, 2017, 2019 e 2021. Os principais resultados e discussões revelaram a insustentabilidade econômico-financeira de três microrregiões: Alto Piranhas, Borborema e Espinharas. A Microrregião do Litoral, além de apresentar condições climáticas mais favoráveis e concentrar mais de $60 \%$ das receitas operacionais diretas da Paraíba, é a única que apresenta sustentabilidade econômico-financeira.

Palavras-chave: Saneamento básico; Regionalização do saneamento; Microrregiões de água e esgoto.

\begin{abstract}
On July 15, 2020, Federal Law No. 14,026 was published, amending a set of laws related to sanitation. This Law established a one-year deadline for the States to create a regionalization structure for sanitation, specifically for water and sewage services. If the states do not implement the water and sewage micro-regions within the established deadline, the sanitation regionalization will be established in a compulsory way by the Union, with the creation of reference blocks. Paraíba, through Complementary Law no. 168 (2021), created four micro-regions: Alto Piranhas, Borborema, Espinharas and Litoral. This article aims to analyze the technical feasibility and the economic-financial and environmental sustainability of these micro-regions. Indicators and information about the Paraíba municipalities made available by the National Sanitation Information System (SNIS), in 2015, 2017 and 2019, such as the financial performance indicator (IN012) and the cash sufficiency index (IN101), and the different water availability scenarios, through the monitoring data of the existing dams in these microregions, in 2015, 2017, 2019 and 2021, were analyzed. The main results and discussions revealed the economic-financial unsustainability of three microregions: Alto Piranhas, Borborema and Espinharas. The Microregion of Litoral, besides presenting more favorable climate conditions and
\end{abstract}


concentrating more than $60 \%$ of the direct operational revenues of Paraíba, is the only one that presents economicfinancial sustainability.

Keywords: Basic sanitation; Sanitation regionalization; Water and sewage microregions.

\section{Resumen}

El 15 de julio de 2020 se publicó la Ley Federal $N^{\circ}$ 14.026, que modifica un conjunto de leyes relacionadas con el saneamiento. Esta Ley estableció un plazo de un año para que los Estados creen una estructura de regionalización del saneamiento, específicamente los servicios de agua y alcantarillado. Si los Estados no implementan las Microrregiones de Agua y Alcantarillado dentro del plazo establecido, la regionalización del saneamiento será obligatoria que establezca la Unión, con la creación de bloques de referencia. Paraíba, a través de la Ley Complementaria no 168 (2021), creó cuatro microrregiones: Alto Pirañas, Borborema, Espinharas y Litoral. Este artículo tiene como objetivo analizar la viabilidad técnica y la sostenibilidad económico-financiera y ambiental de estas microrregiones. Se analizaron indicadores e información sobre los municipios de Paraíba puestos a disposición por el Sistema Nacional de Información de Saneamiento (SNIS) en 2015, 2017 y 2019, como el indicador de desempeño financiero (IN012) y el índice de suficiencia de efectivo (IN101), y las distintas disponibilidades de agua. escenarios, a través de datos de monitoreo de los embalses existentes en estas microrregiones, en 2015, 2017, 2019 y 2021. Los principales resultados y discusiones revelaron la insostenibilidad económica y financiera de tres microrregiones: Alto Pirañas, Borborema y Espinharas. La Microrregión Costera, además de tener condiciones climáticas más favorables y concentrar más del $60 \%$ de los ingresos operativos directos de Paraíba, es la única que presenta sostenibilidad económica y financiera.

Palabras clave: Saneamiento; Regionalización del saneamiento; Microrregiones de agua y alcantarillado.

\section{Introdução}

A Constituição Federal (CF), instituída em 1988, no Brasil, estabelece que os entes federativos possuem competência para promover melhorias no saneamento básico. Cabe à União estabelecer as diretrizes para o desenvolvimento urbano, incluindo o saneamento. $\mathrm{O}$ art. 25 permite a possibilidade de criação de regiões metropolitanas, aglomerações urbanas e microrregiões pelos Estados, mediante Lei Complementar (LC), com a finalidade de integrar a organização, o planejamento e a execução das funções públicas de interesse comum. A União, os Estados, o Distrito Federal e os Municípios disciplinarão, por meio de lei, os consórcios públicos e os convênios de cooperação entre os entes federados, autorizando a gestão associada de serviços públicos (art. 241). Mas, compete aos municípios legislar e decidir sobre os assuntos de interesse local, como o planejamento, a organização e a prestação dos serviços públicos (art. 30), como previsto pela Constituição (1988).

Em 2007, foi criado o Marco Legal do Saneamento, por meio da Lei Federal $\mathrm{n}^{\mathrm{o}}$ 11.445, que estabelece a Política Nacional de Saneamento Básico (PNSB) e as diretrizes para o setor, essa lei foi regulamentada pelo Decreto $\mathrm{n}^{\circ} 7.217$, de 21 de junho de 2010. Em 2020, foi aprovada a Lei Federal n 14.026, que ficou conhecida como "Novo Marco Legal do Saneamento Básico", pois altera um conjunto de leis relacionadas ao saneamento. Ela intervém na Lei Federal n 11.445 (2007) e em outras leis - Lei Federal no 9.984 (2000); Lei Federal n 10.768 (2003); Lei Federal n 11.107 (2005); Lei Federal no 12.305 (2010); Lei Federal no 13.089 (2015); e Lei Federal nº 13.529 (2017) - para que sejam garantidas as alterações propostas na reformulação do Marco Legal (2007).

A Lei Federal no 9.984 (2000) foi alterada para transformar a Agência Nacional de Águas (ANA) em Agência Nacional de Águas e Saneamento Básico (ANA), com competência para editar normas de referência sobre o serviço de saneamento. As modificações realizadas na Lei Federal $n^{\circ}$ 10.768/2003, que dispõe sobre o quadro de pessoal da ANA, criam cargos e atribuições. A alteração na Lei Federal $n^{\circ} 11.107$ (2005), que dispõe sobre normas gerais de contratação de consórcios público e que regulamentou o art. 241 da CF, veda a formalização de novos contratos de programa, convênio ou termos de parceria e determina a obrigatoriedade do processo de concessão dos serviços de saneamento, por meio de licitação. A Lei Federal nº 11.445 (2007) foi a que mais sofreu intervenções, ela teve alguns artigos revogados, outros alterados, inclusão de novos princípios fundamentais e normas de referência para a regulação do setor. A Lei Federal n ${ }^{\circ} 12.305$ (2010) teve prorrogação em prazos de exigências da Política Nacional de Resíduos Sólidos (PNRS). A Lei Federal n ${ }^{\circ} 13.089$ (2015), que institui o Estatuto da Metrópole e regulamenta o art. 25 da $\mathrm{CF}$, foi alterada para estender seu âmbito de atuação às microrregiões de água e esgoto. Entre outras 
modificações na Lei Federal n ${ }^{0} 13.529$ (2017), que permite a participação da União em fundo de apoio à estruturação e ao desenvolvimento de projetos de concessões e parcerias público privadas na administração pública, a Lei Federal no 14.026 (2020) revogou o Parágrafo único, do art. $1^{\circ}$, que dizia: "Até $40 \%$ (quarenta por cento) dos recursos de que trata o caput deste artigo serão preferencialmente utilizados em projetos nas regiões Norte, Nordeste e Centro-Oeste".

Além disso, a Lei Federal no 14.026, publicada no dia 15 de julho de 2020, estabelece que as estruturas regionais de saneamento básico devem ser estabelecidas pelo Estado no prazo de 1 (um) ano da publicação da referida Lei. Caso não sejam instituídas pelos Estados e Distrito Federal, será estabelecida, de forma compulsória pela União, com a criação de blocos de referência para a prestação regionalizada dos serviços públicos de saneamento básico. Nos casos de unidade regional de saneamento básico, blocos de referência e gestão associada, os titulares dos serviços públicos de saneamento terão o prazo de 180 (cento e oitenta) dias contados, o que equivale a 6 (seis) meses, para aderirem à nova estrutura de governança. A adesão dos titulares dos serviços públicos de saneamento de interesse local às estruturas regionais é facultativa, porém a alocação de recursos públicos federais e os financiamentos com recursos da União ou com recursos geridos ou operados por órgãos ou entidades da União estão condicionados à estruturação de prestação regionalizada e à adesão pelos titulares dos serviços públicos de saneamento básico à estrutura de governança correspondente (Art. 50 da Lei Federal no 14.026, 2020). Ou seja, para terem acesso aos recursos federais, os municípios serão condicionados a aderirem a alguma estrutura de governança regionalizada desses serviços.

Outra modificação estabelecida pelo "Novo Marco Regulatório do Saneamento Básico" trata sobre o instrumento econômico de política social, que contribui para a garantia do acesso aos serviços de saneamento por grupos ou localidades de menor renda, que dependem de subsídios cruzados para acessarem determinados serviços públicos, como o abastecimento de água e esgotamento sanitário. Os subsídios cruzados possibilitam que os prestadores estaduais e locais garantam os serviços para os grupos de menor renda, sendo um instrumento indispensável para a universalização do acesso a esses serviços. $\mathrm{O}$ art. 31 da Lei $\mathrm{n}^{\circ} 14.026$ (2020), que dispõe sobre o subsídio cruzado, revoga o inciso I e exclui o subsídio direto e indireto. Dessa forma, inviabiliza os subsídios destinados a usuários determinados e destinados ao prestador de serviços, que eram garantidos pelo Marco Legal do Saneamento (2007).

A Lei $n^{\circ} 14.026$ (2020) incluiu na Lei $n^{\circ} 11.445$ (2007) a possibilidade das outorgas de recursos hídricos, atualmente detidas pelas empresas estaduais, serem segregadas ou transferidas da operação a ser concedida. Sendo permitida a continuidade da prestação do serviço público de produção de água pela empresa detentora da outorga e a assinatura de contrato de longo prazo entre esta empresa e a empresa operadora da distribuição de água para o usuário final, com objeto de compra e venda de água. Incluiu, também, novas normas de referência para a regulação dos serviços públicos de saneamento básico, que, além de contemplar os princípios fundamentais do art. 2 da Lei Federal n ${ }^{\circ} 11.445$ (2007), deverão: (i) "estimular a livre concorrência, a competitividade, a eficiência e a sustentabilidade econômica na prestação dos serviços, por meio da seleção competitiva do prestador"; (ii) "incentivar a regionalização da prestação dos serviços, visando contribuir para a viabilidade técnica e econômicofinanceira, a criação de ganhos de escala e de eficiência, além da universalização dos serviços"; e (iii) "assegurar a prestação concomitante dos serviços de abastecimento de água e de esgotamento sanitário". Além disso, estabelece que as unidades regionais de saneamento básico devem apresentar sustentabilidade econômico-financeira e contemplar, preferencialmente, pelo menos 1 (uma) região metropolitana, facultada a sua integração por titulares dos serviços de saneamento (Lei Federal nº 14.026, 2020).

Foi publicado, no dia 31 de maio de 2021, o Decreto Federal n ${ }^{\circ}$ 10.710, que regulamenta o art. 10-B da Lei Federal $\mathrm{n}^{\circ}$ 11.445 (2007) para estabelecer a metodologia para a comprovação da capacidade econômico-financeira dos prestadores de serviços públicos de água ou esgotamento sanitário, que possuam contratos regulares em vigor. Dentre os requisitos estabelecidos pelo Decreto, vale destacar o que permite, em caráter excepcional, a realização da comprovação da capacidade econômico- 
financeira por estrutura de prestação regionalizada (art. 9), desde que: i) exista prévia definição dessas estruturas e que elas assegurem a viabilidade técnica e econômico-financeira para a universalização desses serviços em todo o Estado; ii) o prestador detenha contratos que possam ser agrupados de modo a atender todos os municípios da estrutura de prestação regionalizada; iii) o prestador assuma a obrigação de construir sociedade de propósito específico (com prazo até o dia 31 de dezembro de 2022); iv) e que o fluxo de caixa global de cada estrutura de prestação regionalizada tenha valor presente líquido igual ou superior a zero. Quanto ao procedimento, estabelece que o prestador deverá apresentar requerimento de comprovação de capacidade econômico-financeira junto a cada entidade reguladora responsável pela fiscalização de seus contratos até 31 de dezembro de 2021 (art. 10). De acordo com esse Decreto, a falta de apresentação de requerimento pelo prestador, implicará a ausência de comprovação de capacidade econômico-financeira do prestador.

O Decreto estabelece que, caso as empresas públicas ou sociedades de economia mista estaduais que prestem serviços públicos de água ou esgotamento sanitário com base em contrato de programa sejam submetidas a processo de desestatização, terão sua capacidade econômico-financeira presumida, desde que atendidas algumas condições. A primeira condição é a apresentação de requerimento pelo controlador, até 31 de janeiro de 2022, às entidades reguladoras competentes para decidir sobre a capacidade econômico-financeira da empresa pública ou sociedade de economia mista, acompanhado de comprovação da contratação dos estudos e dos atos necessários à desestatização junto à instituição financeira, com mandato para venda em caso de viabilidade econômica da operação. A segunda, é a autorização legislativa geral ou específica para a desestatização, até 31 de dezembro de 2022. A terceira, é o atendimento às metas de universalização pelos contratos de concessão que substituirão os contratos de programa para prestação de serviços públicos de abastecimento de água potável ou de esgotamento sanitário, a serem celebrados em conjunto com a desestatização. A quarta, é a realização do processo de desestatização de modo compatível com as estruturas de prestação regionalizada, nos termos do disposto no inciso VI do caput art. $3^{\circ}$ da Lei ${ }^{\circ} 11.445$, de 2007. E a quinta condição é a conclusão da desestatização até 31 de março de 2024 (art. 22 do Decreto Federal n 10.710, 2021).

Na prática, as alterações estabelecidas pela Lei Federal no 14.026 (2020) e pelo Decreto Federal no 10.710 (2021) abrem caminhos para o processo de privatização dos serviços e desestatização das empresas públicas de saneamento, por meio de licitação para concessão dos serviços ou para alienação do controle acionário da estatal prestadora, com a substituição de todos os contratos vigentes (art. 13 da Lei Federal no 14.026, 2020; art. 22 do Decreto Federal no 10.710, 2021). Tais mudanças já estão ocorrendo em alguns estados brasileiros, como foi o caso de Alagoas (AL) e do Rio de Janeiro (RJ), que foram os primeiros, após a referida lei, a dispor os municípios em blocos regionalizados e a implementar a transferência da concessão de serviços públicos de saneamento de empresas estatais, Companhia de Água e Esgoto de Alagoas (CASAL) e Companhia Estadual de Água e Esgoto do Rio de Janeiro (CEDAE), para empresas privadas. Nos casos citados, a concessão da prestação regionalizada dos serviços públicos de distribuição de água e esgotamento sanitário ocorreu por meio de leilões, organizados pelo Governo em parceria com o Banco Nacional de Desenvolvimento Econômico e Social (BNDES), que segue a agenda internacional de desestatização para ampliar o domínio de empresas multinacionais/transnacionais do setor privado sobre os serviços de saneamento, principalmente aqueles que envolvem a água.

Segundo Castro (2016b), os princípios neoliberais que norteiam a privatização da gestão da água e demais serviços de saneamento defendem que a água deve ser considerada um bem econômico a ser regulado pela lógica de mercado e que a noção de que a água é um bem público deve ser abandonada. Assim, as reformas que viabilizam a privatização da água e dos serviços de saneamento são, antes de tudo, mudanças nas normas legais e nas instituições que regulam o setor para que estes bens e serviços possam ser transformados em bens privados (Castro, 2016b), como as propostas pela Lei $\mathrm{n}^{\circ} 14.026$ (2020). O problema é que quando bens e serviços públicos são apropriados pelo mercado para gerar lucro, os cidadãos tendem a ser reduzidos à mera condição de consumidores, o que pode comprometer o acesso universal a esses bens e serviços, caso inexistam políticas públicas que os garantam, enquanto direitos essenciais, independente da capacidade de pagamento dos utilizadores (Castro, 2016a; Castro, 
2016b; Castro, Cunha, Fernandes e Sousa, 2017; e Heller, 2020).

As pressões internacionais para a desestatização de serviços que despertam o interesse do setor econômico, como os de saneamento básico, são antigas, e seguem defendendo a privatização aos serviços e empresas públicas como "solução" para a retomada do crescimento econômico. Chang (2004) já alertava sobre uma enorme pressão que os países em desenvolvimento estavam sofrendo, para adotar as medidas de "boas práticas" políticas e econômicas prescritas pelo Consenso de Washington, que ocorreu em 1989, com o apoio de nações desenvolvidas e organizações internacionais, como o Banco Mundial (BM) e o Fundo Monetário Internacional (FMI), entre outros. Dentre as dez medidas propostas, vale destacar a de privatização de empresas estatais e o livre comércio internacional.

No Brasil, no início da década de 1990, foi criado o Programa Nacional de Desestatização (PND) e houve a formalização da contratação do Projeto de Modernização do Setor de Saneamento (PMSS), criado e financiado pelo Banco Mundial. Em 1999, o governo firmou um acordo com o FMI para ampliar o programa de privatizações e concessões dos serviços de água e esgoto, mas não teve muito sucesso (Salles, 2009). Um dos riscos quando serviços públicos e direitos humanos seguem a lógica mercantilista, e deixam de ser garantidos pelo Estado, é que serviços essenciais, como o abastecimento de água e o saneamento, passem a ser reorganizados com base no princípio da exclusão, visando ganhos econômicos. Quando, na verdade, deveriam seguir o princípio da inclusão social, visando a universalização destes serviços e direitos (Castro, 2016b).

As tentativas de privatizar empresas estatais de serviços de saneamento foram muitas e seguem ocorrendo. Dessa vez, o Governo Federal e demais interessados implementaram reformas no âmbito legislativo e institucional, que abrem o setor do saneamento para o livre mercado, de forma a induzir o processo de privatização regionalizada dos serviços e/ou de unidades regionais. Além disso, o processo de regionalização dos serviços de saneamento e os leilões para a concessão privada estão sendo conduzidos de forma antidemocrática e sem transparência, tanto pela União, como por alguns Estados. Nesse contexto, a pandemia da COVID-19, que já vitimou mais de 540 mil brasileiros, até o dia 17 de julho de 2021, tem sido utilizada oportunamente para justificar a ausência do debate presencial. No entanto, não justifica o reduzido debate remoto, com pouca ou nenhuma divulgação, transparência e aprofundamento sobre a temática. A pandemia deveria ser um dos motivos para justificar a necessidade do amplo debate e da ampla participação, já que a ausência de acesso aos serviços de abastecimento de água e saneamento criam condições de insalubridade prejudiciais à saúde pública.

O controle social e democrático na gestão da água e dos serviços públicos de saneamento é necessário para que eles não sejam geradores e reprodutores de desigualdades e injustiças socioambientais. Segundo Castro, as visões predominantes no setor de saneamento destacam a dimensão técnica e administrativa do problema, como se as atividades de controle social e gestão dos serviços estivessem isoladas dos processos socioeconômicos, culturais e políticos. Se, por um lado, há um crescente reconhecimento discursivo da necessidade de participação e controle social, na prática, as visões tecnocráticas e a influência de políticas neoliberais são dominantes, o que prejudica a democratização do setor do saneamento (Castro, 2016a; Castro, 2016b).

Na Paraíba, o processo de regionalização foi proposto através do Projeto de Lei Complementar (PLC) (2021a), de 30 de maio de 2021, de autoria do Governo do Estado para a criação das microrregiões de água e esgoto: Alto Piranhas, Borborema, Espinharas e Litoral, além de suas respectivas estruturas de governança. Este artigo pretende discutir tecnicamente, de forma clara, didática e ilustrativa, como se deu esse processo e a caracterização dessas microrregiões com o objetivo de informar e analisar aspectos relevantes sobre essas questões, que foram ou não abordadas pelo Estudo Técnico (2021). Para isso, foram utilizados indicadores econômico-financeiros do Sistema Nacional de Informações sobre Saneamento (SNIS), em 2015, 2017 e 2019, para analisar a viabilidade técnica e a sustentabilidade econômico-financeira dessas microrregiões. Foram utilizados, também, dados de capacidade hídrica, situação dos açudes e do abastecimento nos municípios paraibanos (AESA), em 2015, 2017, 2019 e 2021, para analisar os cenários distintos de disponibilidade hídrica das microrregiões.

No que se refere ao processo de regionalização, houve apenas uma audiência pública para apresentar a Minuta da Lei 
Complementar (PLC, 2021a). Inicialmente, ocorreria em uma plataforma de reunião online, mas foi redirecionada para outra plataforma, onde seria transmitida para os demais participantes. A audiência realizada pelo Governo do Estado, por intermédio da Secretaria da Infraestrutura, dos Recursos Hídricos e do Meio Ambiente (SEIRHMA), ocorreu no dia 18 de maio de 2021, e foi transmitida através do canal da SEIRHMA, no YouTube. A mesa virtual foi composta pelo secretário da SEIRHMA, Deusdete Queiroga, pelo consultor jurídico Wladimir Antônio Ribeiro e pelo responsável técnico da proposta de regionalização do saneamento da Paraíba, Rudinei Toneto Júnior. A transmissão durou cerca de três horas, mas o estudo técnico não foi apresentado. Os integrantes da mesa abordaram, de forma geral e superficial, a temática da regionalização, sem tratar de questões mais específicas da Paraíba e sem apresentar dados de viabilidade econômico-financeira das microrregiões de água e esgoto.

Cerca de 180 (cento e oitenta) pessoas acompanharam a transmissão e, pelo formato da audiência, os participantes não tinham direito a voz, apenas poderiam enviar suas perguntas na forma escrita, pelo chat do YouTube, que seriam respondidas ao final. Muitas perguntas não foram respondidas durante essa audiência, mas os integrantes da mesa se comprometeram em responder posteriormente, o que foi feito por meio do Anexo V da Lei Complementar n. 168 (2021), que apresenta as perguntas mais frequentes durante a audiência pública e suas respectivas respostas. Além da audiência, houve um período de consulta pública, que foi realizada através de formulário online, do dia 30 de abril ao dia 30 de maio de 2021, no entanto, o estudo técnico não estava disponível para análise da comunidade durante este período (SEIRHMA PB, 2021).

A Assembleia Legislativa da Paraíba (ALPB) realizou, no dia 15 de junho de 2021, uma reunião da Comissão de Desenvolvimento, Turismo e Meio Ambiente para abortar a temática da regionalização do saneamento e o PLC (2021a). A reunião contou com a participação de alguns deputados, professores, representantes de sindicatos e outros interessados na pauta abordada, no entanto, os responsáveis pelo PLC, embora tenham sido convidados, não enviaram nenhum representante para apresentar a proposta e esclarecer as dúvidas (TV ASSEMBLEIA PB, 2021a).

Na noite do dia 16 de junho de 2021, deu entrada no protocolo da ALPB o estudo técnico, que ainda não havia sido divulgado, e um PLC (2021b) diferente do que havia sido apresentado em audiência pública, com inclusão de novos incisos, parágrafos e artigos. Além disso, nem mesmo os parlamentares tiveram acesso prévio ao estudo técnico, que data do mês de maio. Mas foi disponibilizado com menos de 24 horas de antecedência para o início da $26^{\circ}$ Sessão Ordinária da ALPB, que começou às 09:00h, do dia 17 de junho de 2021, e, após 3 horas de sessão, foi aprovada a Lei Complementar (TV ASSEMBLEIA PB, 2021b). No dia 22 de junho de 2021, foi criada a Lei Complementar No 168 , publicada no dia seguinte, no Diário Oficial do Estado da Paraíba (Diário Oficial, 2021).

O estudo que trata das Microrregiões de Água e Esgoto da Paraíba foi desenvolvido pela Fundação para Pesquisa e Desenvolvimento da Administração, Contabilidade e Economia (FUNDACE), de Ribeirão Preto, São Paulo. Um documento técnico, com mais de 200 páginas, que não foi disponibilizado com antecedência, nem amplamente divulgado e, o mais grave, não foi exaustivamente discutido pelos atores envolvidos. Mesmo assim, o PLC (2021b) foi aprovado pela Assembleia Legislativa da Paraíba. Dos trinta e dois deputados estaduais, $75 \%$ foram favoráveis, dos demais $25 \%$, apenas um se absteve e outros sete deputados foram contrários à aprovação, são eles: Anderson Monteiro; Camila Toscano; Cida Ramos; Estela Bezerra; Jeová Campos; Tovar Correia e o Cabo Gilberto. Esses deputados se manifestaram contra a forma como o processo de apreciação e discursão da matéria ocorreu, criticaram a urgência da votação e como o processo para a aprovação do PLC foi conduzido, pela falta de debate, transparência e ausência de esclarecimentos sobre o estudo técnico e a proposta das microrregiões de água e esgoto. Criticaram o fato de não haver na sessão ordinária representantes da Companhia de Água e Esgoto da Paraíba (CAGEPA), da Agência Executiva de Gestão das Águas (AESA), da Secretaria da Infraestrutura, dos Recursos Hídricos e do Meio Ambiente (SEIRHMA) e demais responsáveis pelo PLC, diante da relevância do tema e da necessidade do debate para a aprovação da Lei Complementar (TV ASSEMBLEIA PB, 2021b).

A problemática não está expressa na regionalização do saneamento, imposta pela atual legislação vigente, mas, em 
como esse processo está sendo conduzido no Brasil e como alguns estados brasileiros estão replicando ações antidemocráticas, centralizadoras e tecnocratas. Ações que podem definir o futuro dos serviços de água e saneamento no país e afetar a vida de toda população brasileira, e, por isso, requer responsabilidade e a efetiva participação dos atores envolvidos, visando o bem comum e a universalização desses serviços. Não garantir o acesso à informação, com a publicidade como preceito geral e o sigilo como exceção; a transparência e divulgação de informações de interesse público, independente de solicitações; o desenvolvimento do controle social e da participação na gestão pública, é violar direitos (Lei Federal n ${ }^{\circ}$ 12.527, 2011).

De acordo com o art. 5 da Lei Federal no 12.527 (2011), "é dever do Estado garantir o direito de acesso à informação, que será franqueada, mediante procedimentos objetivos e ágeis, de forma transparente, clara e em linguagem de fácil compreensão". Cabe aos órgãos e entidades do poder público assegurar a gestão transparente da informação, garantindo o amplo acesso e a sua divulgação. Dentre outras, constituem condutas ilícitas (Art. 32): recusar-se a fornecer informação requerida, retardar deliberadamente o seu fornecimento ou fornecê-la de forma incorreta, incompleta e imprecisa; utilizar indevidamente, subtrair, destruir, desfigurar, alterar ou ocultar, total ou parcialmente, informação que se encontre sob sua guarda ou a que tenha acesso ou conhecimento em razão do exercício das atribuições de cargo, emprego ou função pública; e agir com dolo ou má-fé na análise das solicitações de acesso à informação.

\section{Metodologia}

\subsection{Procedimentos Metodológicos}

O que impulsiona o homem em direção à ciência, segundo Koche (2011), é a necessidade de compreender a cadeia de relações que se esconde por trás das aparências sensíveis dos objetos, fatos ou fenômenos. A investigação científica visa produzir conhecimento científico, sendo a função do pesquisador propor uma forma sistemática, metodológica e crítica de desvelar o mundo, explicar e tornar a compreensão acessível sobre as coisas, os fatos e os fenômenos estudados (Koche, 2011).

A dificuldade de acesso aos dados e estudos que serviram de base para a criação das Microrregiões de Água e Esgoto da Paraíba, motivaram o desenvolvimento desta pesquisa, que traz uma abordagem exploratória, descritiva e explicativa sobre o processo de regionalização. Trata-se de um Estudo de Caso (EC) com aplicação de métodos de pesquisa quali-quantitativa pela articulação das duas dimensões na coleta, organização e análise dos dados, que compõem as etapas dos procedimentos metodológicos adotados (Figura 1).

Yin (2015) define o EC como uma estratégia de investigação empírica sobre um fenômeno contemporâneo, que está dentro do contexto da vida real, e compreende um método abrangente, que incorpora algumas técnicas de coleta e análise de dados. O EC possibilita a descrição e a análise mais detalhada da problemática e dos fenômenos envolvidos na pesquisa, de forma que a riqueza de informações e de dados podem contribuir para o desenvolvimento do conhecimento na área em que se aplica esse estudo (Yin, 2013; Pereira et al., 2018). A aplicação de métodos qualitativos e quantitativos foram feitas de forma complementar para permitir uma melhor compreensão sobre o processo de criação das Microrregiões de Água e Esgoto da Paraíba e a caracterização dessas áreas. 
Figura 1: Fluxograma síntese das etapas dos procedimentos metodológicos.

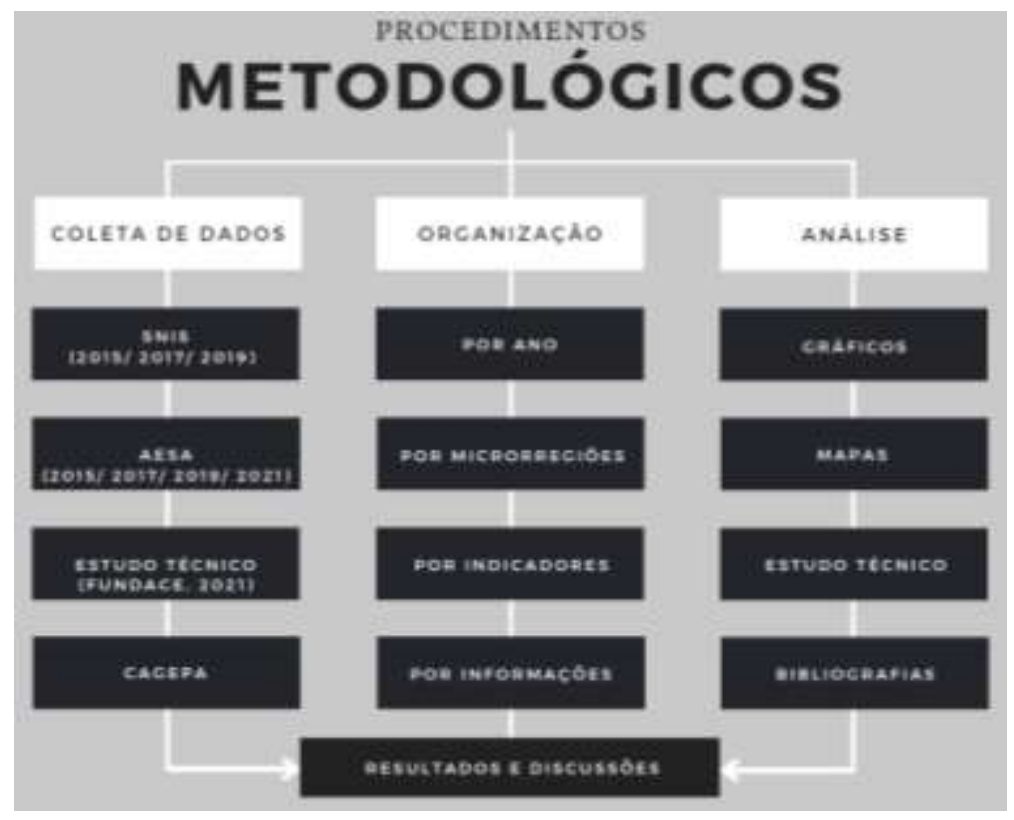

Fonte: Autores (2021).

A coleta de dados foi realizada por meio de acesso online: aos indicadores e informações sobre os serviços de água e esgotamento sanitário dos municípios paraibanos e dados da CAGEPA, disponíveis no SNIS, em série histórica; ao Geo Portal da AESA, onde foi possível obter os dados da situação das adutoras por municípios e de monitoramento do volume dos açudes da Paraíba; ao PLC e ao Estudo Técnico (FUNDACE, 2021), que foi disponibilizado pelo Governo da Paraíba após a aprovação da Lei Complementar $N^{\circ} 168$ (17 de junho de 2021).

Os dados coletados foram organizados por ano, em planilhas em formato CSV ou XLSX (Excel), onde foram inseridos os dados das microrregiões aos demais dados dos municípios. As planilhas foram acessadas por meio de download online, ou tabelas de atributos, acessadas através de shapefile e convertidas em planilhas com o uso do software livre Quantum GIS (QGIS). Essas planilhas já possuíam os indicadores e as informações associadas aos municípios e disponibilizadas por instituições públicas ou sistemas de informações com acesso livre (SNIS e AESA). Foram selecionados apenas alguns desses indicadores e informações para gerar tabelas, gráficos e mapas, que podem contribuir de forma significativa para o desenvolvimento desse estudo e para a compreensão por parte dos leitores.

\subsection{Indicadores e Informações}

Os indicadores selecionados do Sistema Nacional de Informações sobre Saneamento [SNIS] (2018) para a análise da sustentabilidade econômico-financeira das microrregiões de água e esgoto da Paraíba foram: o indicador de desempenho financeiro (IN012) e o índice de suficiência de caixa (IN101). O IN012 é composto por FN001 - que é a soma da receita operacional direta de água (FN002), com a receita operacional direta de esgoto (FN003), a receita operacional de água exportada (bruta ou tratada) (FN007) e a receita operacional direta - esgoto bruto importado (FN038) - dividido por FN017, que corresponde às despesas totais com os serviços (DTS). O IN101 é a arrecadação total (FN006) dividida pela soma das despesas - despesas de exportação (DEX) (FN015), despesas com juros e encargos do serviço da dívida (FN016), despesas fiscais ou tributárias não computadas na DEX (FN022) e despesas com amortizações do serviço da dívida (FN034). Esses indicadores foram calculados por Microrregiões de Água e Esgoto da Paraíba, Lei Complementar $n^{\circ} 168$ (2021), para compreender os cenários econômico-financeiros a partir dos resultados dos dados e indicadores dos municípios que pertencem a cada 
microrregião, nos anos de 2015, 2017 e 2019 (Quadro 1).

Quadro 1: Indicadores e informações envolvidas do SNIS.

\begin{tabular}{|c|c|c|}
\hline \multicolumn{3}{|l|}{ IN012 - Indicador de desempenho financeiro } \\
\hline Forma de cálculo & Informações envolvidas & Unidade \\
\hline$\frac{\text { FN001 }}{\text { FN017 }} \times 100$ & $\begin{array}{l}\text { FN002: Receita operacional direta de água } \\
\text { FN003: Receita operacional direta de esgoto } \\
\text { FN007: Receita operacional direta de água exportada (bruta ou tratada) } \\
\text { FN017: Despesas totais com os serviços (DTS) } \\
\text { FN038: Receita operacional direta - esgoto bruto importado }\end{array}$ & percentual \\
\hline Comentários: FN001 = FN002 + FN003 + FN007 + FN038 & & \\
\hline \multicolumn{3}{|l|}{ IN101 - Índice de suficiência de caixa } \\
\hline Forma de cálculo & Informações envolvidas & Unidade \\
\hline$\frac{F N 006}{F N 015+F N 034+F N 016+F N 022} \times 100$ & $\begin{array}{l}\text { FN006: Arrecadação total } \\
\text { FN015: Despesas de Exploração (DEX) } \\
\text { FN016: Despesas com juros e encargos do serviço da dívida } \\
\text { FN022: Despesas fiscais ou tributárias não computadas na DEX } \\
\text { FN034: Despesas com amortizações do serviço da dívida }\end{array}$ & percentual \\
\hline
\end{tabular}

Fonte: Glossário de Indicadores, SNIS (2018).

As informações sobre capacidade hídrica, volume dos açudes das microrregiões e situação das adutoras por municípios foram calculadas a partir da distribuição desses municípios nas microrregiões: Alto Piranhas, Borborema, Espinharas e Litoral. Dessa forma, foi possível calcular a soma da capacidade máxima dos açudes e do volume atual de água nesses reservatórios por cada microrregião. As informações sobre a situação das adutoras por municípios foram obtidas através de dados georreferenciados, disponíveis no Geo Portal da AESA. A tabela de atributos do shapefile foi exportada em formato de planilha para que os dados fossem organizados por microrregiões e fosse possível gerar os gráficos. Assim, foi possível calcular o quantitativo/percentual de municípios em situação de abastecimento satisfatório, em ampliação do sistema produtor, com baixa garantia hídrica e sem informação.

Os dados demográficos e socioeconômicos têm como fonte o Estudo Técnico (FUNDACE, 2021), que abordou os dados em tabelas de acordo com as microrregiões. Além disso, serão abordados alguns dos indicadores e informações mais relevantes utilizados pelo estudo técnico e outros que não estão presentes nesse estudo, mas são de extrema importância para a análise de viabilidade técnica e econômico-financeira dessas microrregiões.

O primeiro passo foi a definição dos indicadores e informações a serem abordados nessa pesquisa, em seguida, foram definidos os anos (Figura 2). No caso do SNIS, os dados mais recentes são de 2019, por essa razão optou-se por trabalhar com esses dados e estabelecer um intervalo de 2 em 2 anos, incluindo os dados de 2017 e 2015, para ter cenários distintos em relação aos condicionantes climáticos, que afetaram a demanda hídrica e os serviços de abastecimento de água na Paraíba, nesses anos. Em relação aos dados de monitoramento dos açudes pela AESA, optou-se por trabalhar com os mesmos anos dos dados do SNIS e acrescentar o ano de 2021, já que esses dados são disponibilizados mensalmente. As informações sobre a situação das adutoras são de novembro de 2020, disponibilizado pela AESA, em formato shapefile. 
Figura 2: Indicadores e informações utilizados.

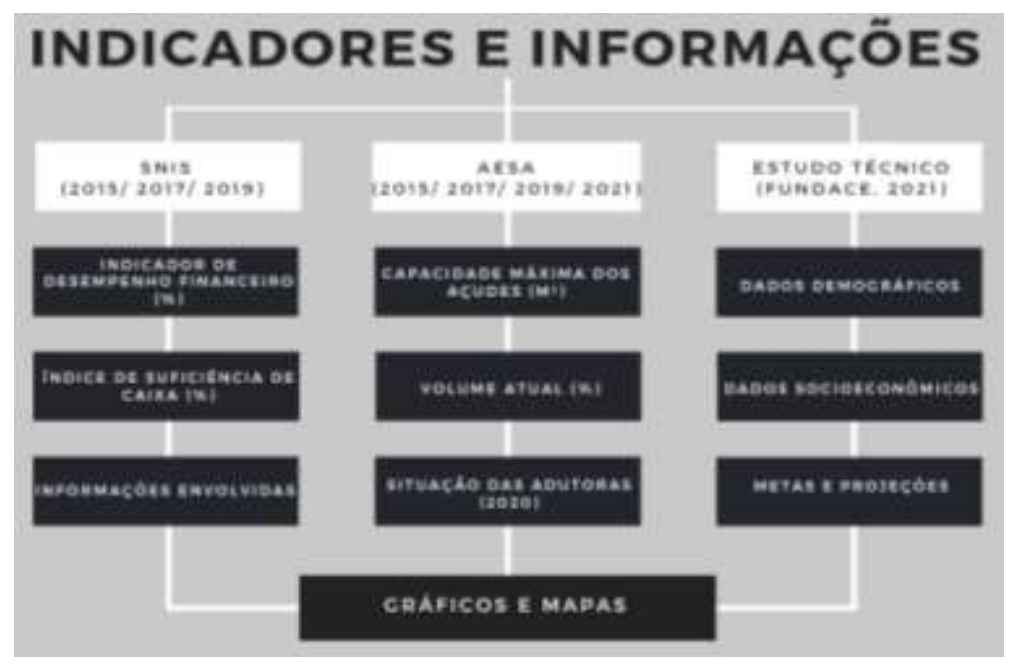

Fonte: Autores (2021).

Os mapas foram elaborados a partir dos dados estruturados em planilhas com a inclusão dos códigos dos municípios, definidos pelo Instituto Brasileiro de Geografia e Estatística (IBGE), e das microrregiões definidas pelo Estudo Técnico (2021) e instituídas por Lei Complementar. Para a elaboração das tabelas e dos gráficos, utilizou-se a ferramenta do Excel, que permite transformar os dados da planilha em gráficos.

\section{Resultados e Discussão}

\subsection{Microrregiões de Água e Esgoto da Paraíba}

\section{Aspectos Demográficos e Socioeconômicos}

Os municípios paraibanos foram distribuídos em quatro Microrregiões de Água e Esgoto, que se diferenciam por aspectos geográficos, socioeconômicos, demográficos, entre outros (Figuras 3 e 4):

1. Microrregião do Alto Piranhas, que é composta por $17 \%$ dos municípios paraibanos (38) e uma população de quase 11\% da população total do Estado (439 mil habitantes), e abrange 17\% da área total da Paraíba;

2. Microrregião da Borborema, que possui $38 \%$ dos municípios (84) e mais de $32 \%$ da população paraibana $(1,28$ milhões de habitantes), em uma área que corresponde a $43 \%$ do território estadual;

3. Microrregião de Espinharas, que abrange 21\% dos municípios (46) e 11\% da população estadual (464 mil habitantes) e ocupa uma área de $25 \%$ da Paraíba; e

4. Microrregião do Litoral, que abrange $25 \%$ dos municípios (55) e uma população de quase $46 \%$ (1,85 milhões de habitantes) em uma área que corresponde a 15\% do território paraibano. 
Figura 3: Caracterização das Microrregiões de Água e Esgoto da Paraíba.

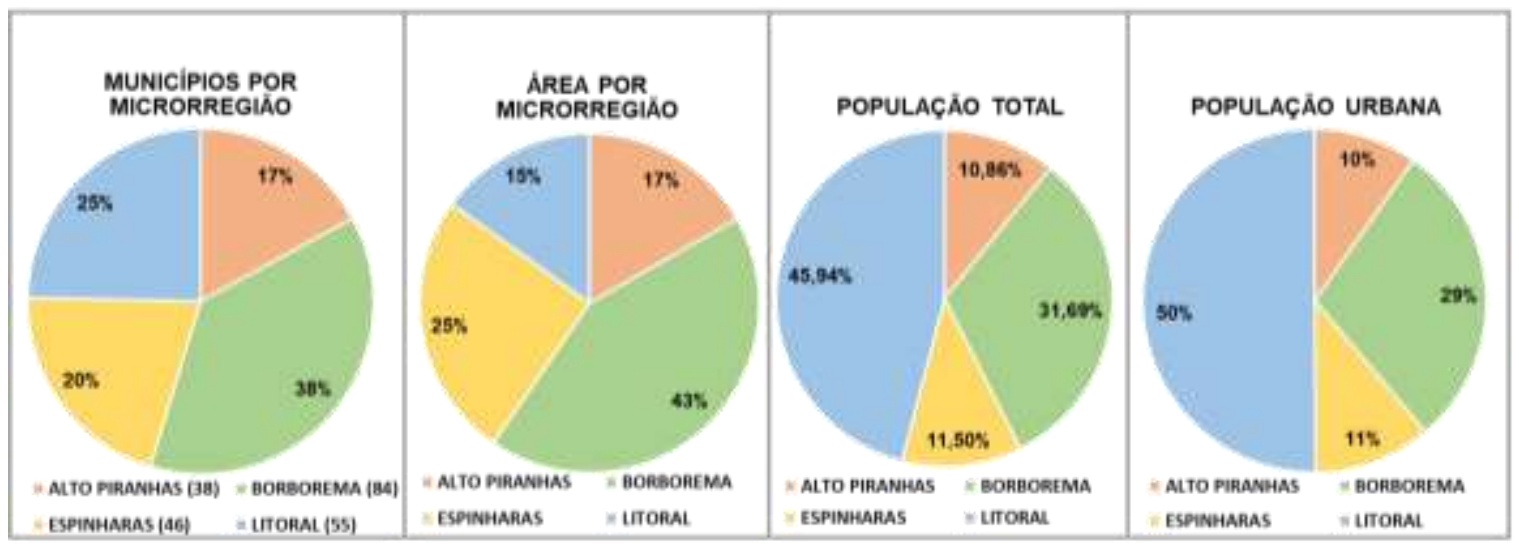

Fonte: Autores com base em dados do Estudo Técnico (2021).

A população urbana da Paraíba está distribuída de forma desproporcional entre as Microrregiões, com um baixo índice percentual em Alto Piranhas e Espinharas, 10 e 11\%, respectivamente. Por outro lado, há uma maior concentração da população urbana no Litoral e na Borborema, que somam 82\% da população urbana da Paraíba, sendo que 50\% pertencem ao Litoral e os outros $32 \%$ a Borborema.

Figura 4: Microrregiões de Água e Esgoto da Paraíba.

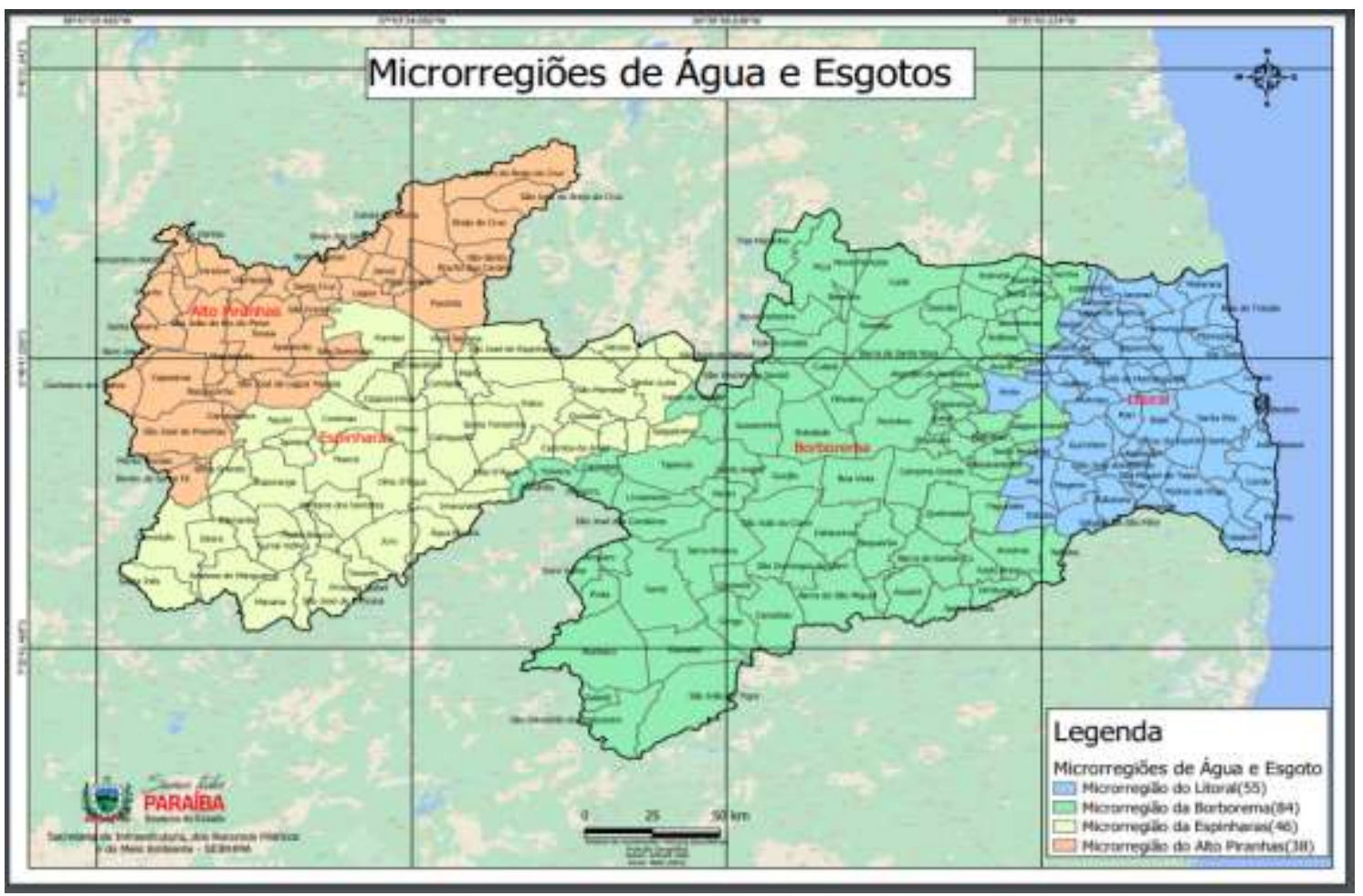

Fonte: SEIRHMA (2021).

Antes de abordar as microrregiões por faixa populacional dos municípios (Figura 5) é relevante informar a quem compete direcionar os recursos federais para os municípios de menor e de maior porte, considerando, respectivamente, os municípios abaixo e acima de 50 mil habitantes. No caso do abastecimento de água, esgotamento sanitário e manejo de resíduos sólidos urbanos em municípios com população superior a 50 mil habitantes ou integrantes de Regiões Metropolitanas, Regiões Integradas de Desenvolvimento ou participantes de Consórcios Públicos afins, atualmente, a competência é do Ministério do 
Desenvolvimento Regional (MDR), por meio da Secretaria Nacional de Saneamento (SNS). Nos municípios de menor porte, a SNS só atua com recursos onerosos, provenientes de financiamento, a serem investidos nas modalidades de abastecimento de água e esgotamento sanitário. $\mathrm{O}$ atendimento dos municípios de menor porte com recursos não onerosos, oriundos do Orçamento Geral da União (OGU), é realizado pelo Ministério da Saúde (MS), por intermédio da Fundação Nacional de Saúde (Funasa), que possui competência para atuar no saneamento desses municípios (Secretaria Nacional de Saneamento, 2020).

Em relação à faixa populacional dos municípios paraibanos, apenas 10 municípios possuem mais de 50 mil habitantes. Ou seja, a Paraíba possui 213 municípios com menos de 50 mil habitantes, o que corresponde a 95,5\% do total de municípios do Estado (Figura 5). Esses municípios estão sob competência da Funasa, vinculada ao MS, e os demais, menos de 5\% dos municípios, estão sob a competência da Secretaria Nacional de Saneamento, vinculada ao MDR. A Lei Complementar 168/2021 e o Estudo Técnico (2021) não abordam essa questão. Com a proibição dos convênios e contratos de programa, há de se questionar: como ficará a questão da competência da SNS e da Funasa e como os recursos federais serão direcionados para as microrregiões e distribuídos para os municípios?

Figura 5: População total dos municípios paraibanos.

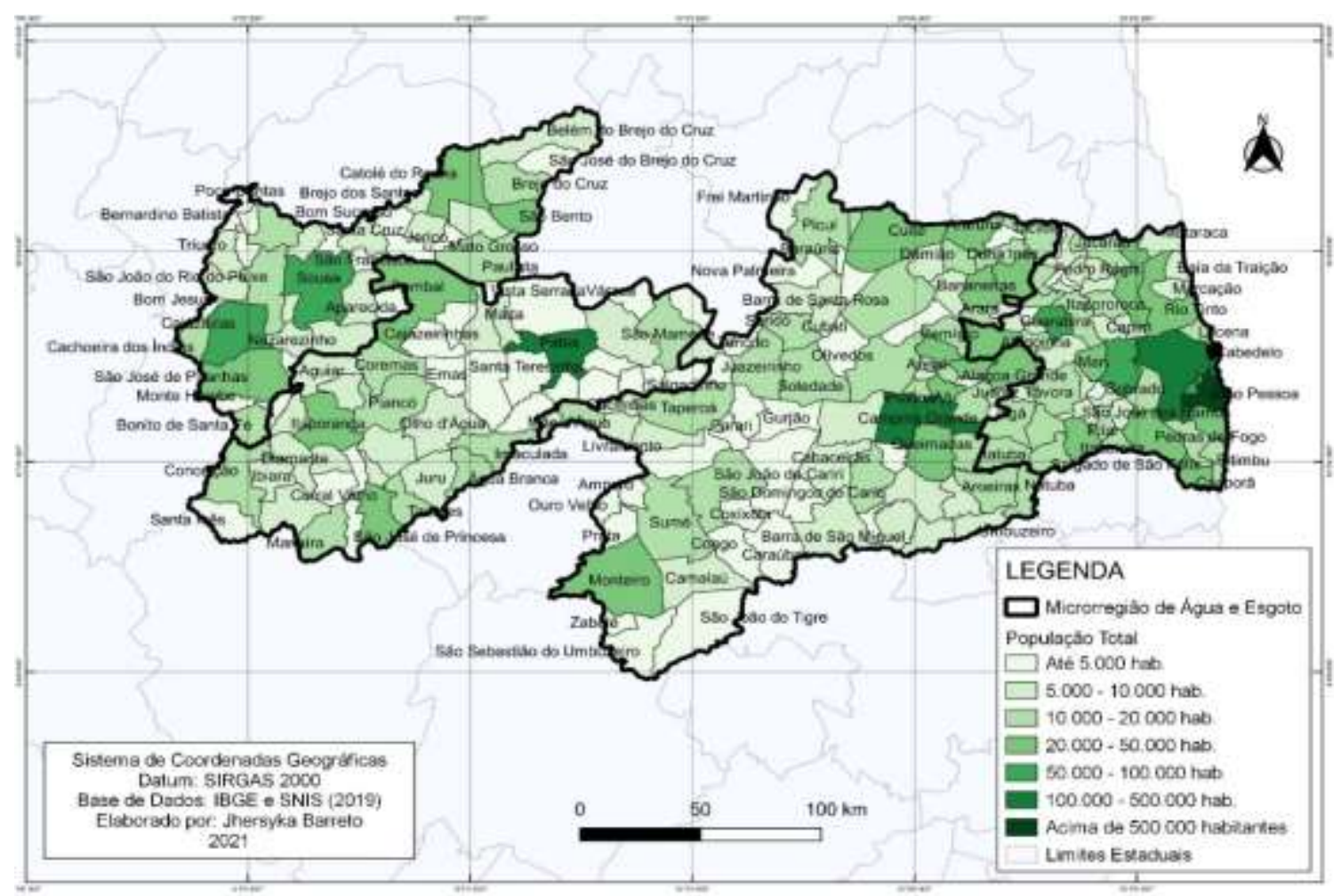

Fonte: Autores, com base na estimativa do IBGE e dados disponíveis no SNIS (2019).

Alto Piranhas apresenta 5,3\% dos seus municípios com população acima de 50 mil habitantes e $30 \%$ de toda a população dessa microrregião, está situada nesses municípios. Borborema possui apenas 1,2\%, que corresponde ao município de Campina Grande, que concentra 32,2\% da população da microrregião. Espinharas possui apenas Patos com população acima de 50 mil habitantes, o que corresponde a 2,2\% dos municípios da microrregião, com uma concentração de $23,3 \%$ da população de toda a microrregião. E a Microrregião do Litoral apresenta $11,0 \%$ dos seus municípios em faixas populacionais acima de 50 mil habitantes, sendo que esses municípios concentram $66,2 \%$ de toda a sua população (Quadro 2). 
Quadro 2: Municípios com população acima de 50 mil habitantes.

\begin{tabular}{|c|c|c|c|}
\hline $\begin{array}{c}\text { Microrregiões de } \\
\text { água e esgoto }\end{array}$ & $\begin{array}{c}\text { Municípios com população } \\
\text { acima de 50 mil habitantes }\end{array}$ & $\begin{array}{c}\text { Percentual em relação ao } \\
\text { total de municípios por } \\
\text { microrregião (\%) }\end{array}$ & $\begin{array}{c}\text { Percentual da população } \\
\text { concentrada nesses municípios } \\
(\%)\end{array}$ \\
\hline ALTO PIRANHAS & Cajazeiras e Sousa & 5,3 & 30,0 \\
\hline ESPINHARAS & Campina Grande & 1,2 & $\mathbf{3 2 , 2}$ \\
\hline LITORAL & $\begin{array}{c}\text { Payeux; Cabedelo; } \\
\text { Guarabira; João Pessoa; } \\
\text { Santa Rita e Sapé }\end{array}$ & $\mathbf{2 , 2}$ & $\mathbf{6 6 , 2}$ \\
\hline
\end{tabular}

Fonte: Autores com base em dados do Estudo Técnico (2021).

Dessa forma, nota-se que a Microrregião de Água e Esgoto do Litoral se destaca pela diferença em relação ao percentual de municípios com população acima de 50 mil habitantes e a concentração da população da microrregião nesses municípios, sendo mais que o dobro quando comparada com as outras microrregiões. O tamanho populacional dos municípios influencia diretamente na taxa de urbanização deles e das microrregiões, como é possível observar no Gráfico 1, em que o percentual de mais de $70 \%$ da população da Microrregião do Litoral está concentrado em municípios com faixa de urbanização de 80 a $100 \%$. Enquanto as demais microrregiões apresentam menos de 50\% da sua população em municípios dentro dessa faixa de urbanização (Gráfico 1). Esses aspectos podem influenciar, também, no processo de universalização do acesso aos serviços de água e esgotamento sanitário, pois a situação das infraestruturas existentes e soluções para o saneamento variam para o contexto urbano e rural de cada município/microrregião, assim como os recursos a serem investidos para alcançar a universalização.

Gráfico 1: População de cada microrregião por faixa de urbanização (\%).

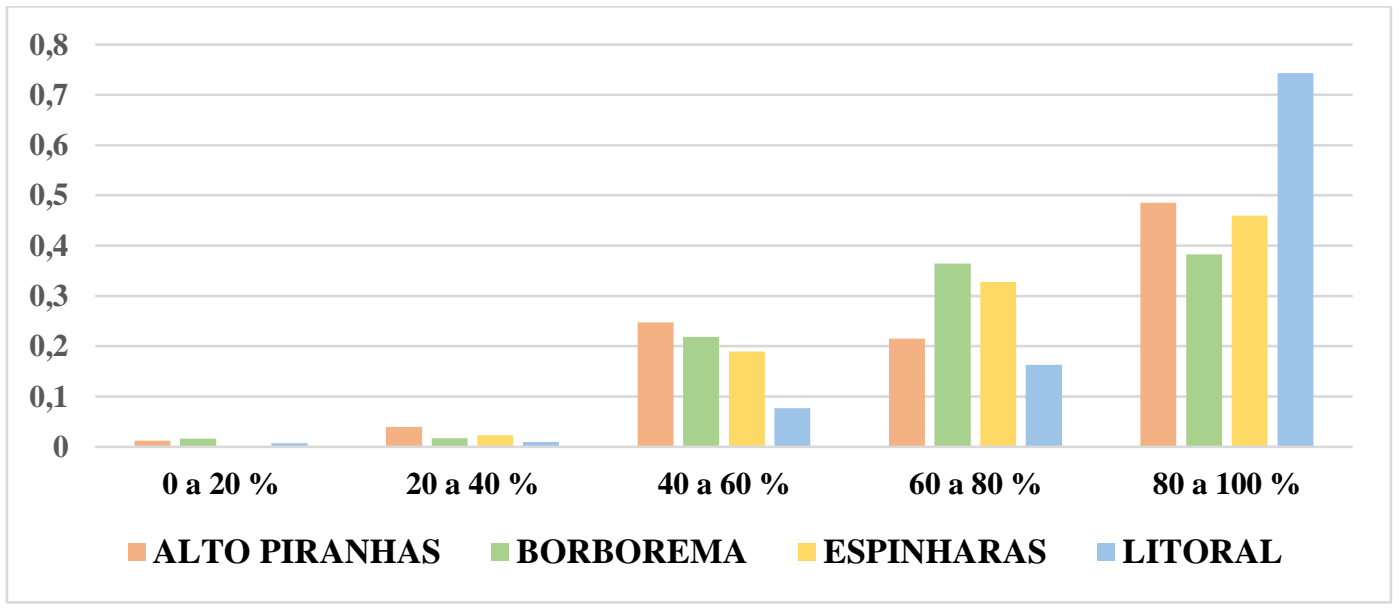

Fonte: Autores com base em dados do Estudo Técnico (2021).

Outros aspectos relevantes a serem abordados de forma comparativa entre as microrregiões são os indicadores socioeconômicos, como o Produto Interno Bruto (PIB) e o Índice de Desenvolvimento Humano Médio (IDHM). Em relação a distribuição do PIB do estado pelas microrregiões, cerca de 56,2\% do PIB está concentrado nos municípios da Microrregião do Litoral; Borborema apresenta 27,5\% do PIB estadual; Alto Piranhas e Espinharas apresentam situação semelhante em relação à participação no PIB da Paraíba, com 8,2\% e 8,1\%, respectivamente (Gráfico 2). Nota-se a disparidade que há entre as microrregiões e a concentração das atividades econômicas na Microrregião do Litoral, seguida da Microrregião da Borborema, que juntas somam $83,7 \%$ do PIB da Paraíba. 
Gráfico 2: Distribuição do PIB do estado (2018) por microrregiões (\%).

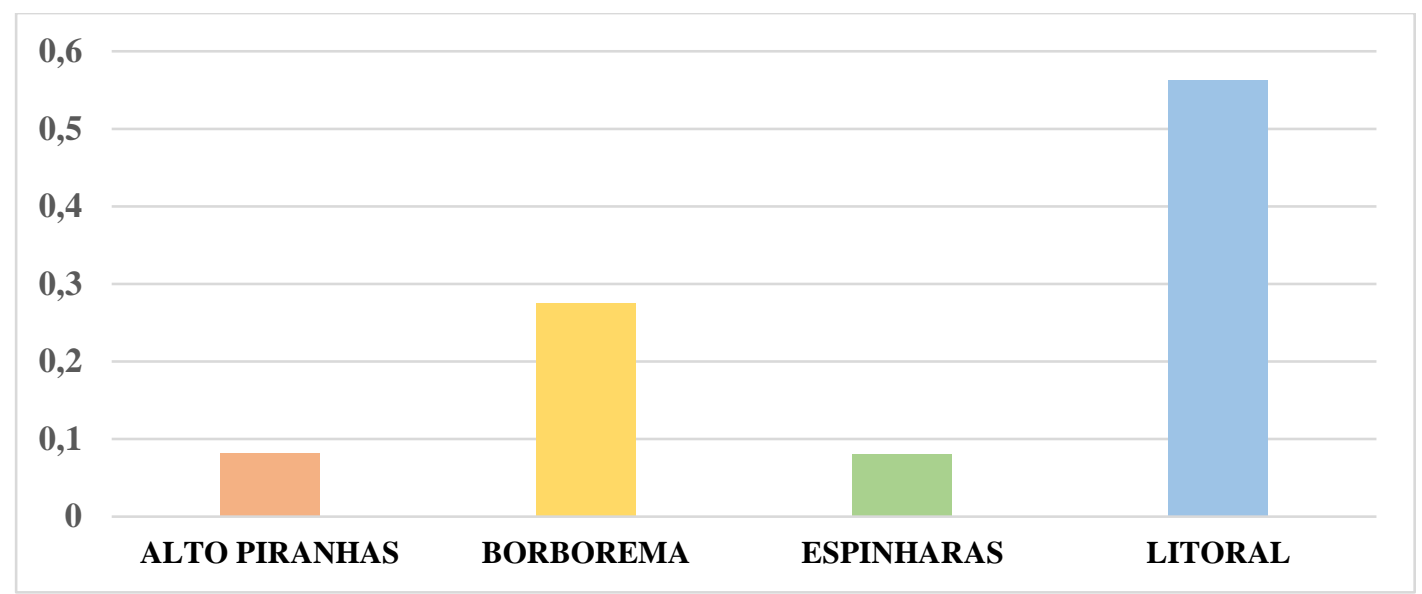

Fonte: Elaborado pelos autores com base em dados do Estudo Técnico (2021).

O Estudo Técnico (2021), compara as quatro microrregiões em vários aspectos como se fossem homogêneas em relação aos dados analisados. No caso dos dados socioeconômicos, destacam-se trechos como: “Ao olhar para o Produto Interno Bruto (PIB), nota-se padrão semelhante.”; e, em outro trecho na mesma página, "Isto porque as microrregiões são mais homogêneas em termos do Índice de Desenvolvimento Humano Municipal médio e da taxa de urbanização, assim como do PIB per capita (medida da renda)" (p. 18). No entanto, não é isso que mostram os dados, pois estes evidenciam realidades socioeconômicas distintas entre as microrregiões, como foi abordado em relação a urbanização e a distribuição do PIB estadual.

Quando se trata do PIB per capita, que divide o valor do PIB pela quantidade de habitantes, temos que cerca de $40 \%$ da população de Alto Piranhas e Borborema estão na faixa de menos de 10 mil reais, cerca de 53\% da população de Espinharas e, aproximadamente, $16 \%$ da população do Litoral também se encontram nessa faixa. Os outros $60 \%$ da população de Alto Piranhas estão divididos: $30 \%$ na faixa de 10 a 15 mil e $30 \%$ na faixa de 15 a 20 mil reais. Borborema apresenta $24 \%$ da sua população na faixa de 10 a 15 mil reais, apenas 3\% na faixa de 15 a 20 mil e cerca de 33\% na faixa de 20 a 30 mil. Espinharas possui $20 \%$ da sua população com PIB per capita na faixa dos 10 a 15 mil reais, cerca de $26 \%$ na faixa entre 15 e 20 mil e apenas $1 \%$ na faixa de 20 a 30 mil reais. A Microrregião do Litoral, apresenta $22 \%$ na faixa de 10 a 15 mil reais, cerca de $11 \%$ estão na faixa de 15 a 20 mil e mais de 50\% da sua população está distribuída em faixas de PIB per capita acima de 20 mil, sendo $46 \%$ na faixa de 20 a 30 mil e, aproximadamente, 5\% na faixa de mais de 30 mil reais, o único que apresenta população com esse PIB per capita (Gráfico 3). 
Gráfico 3: Distribuição da população por faixa de PIB per capita (2018) por microrregiões (\%).

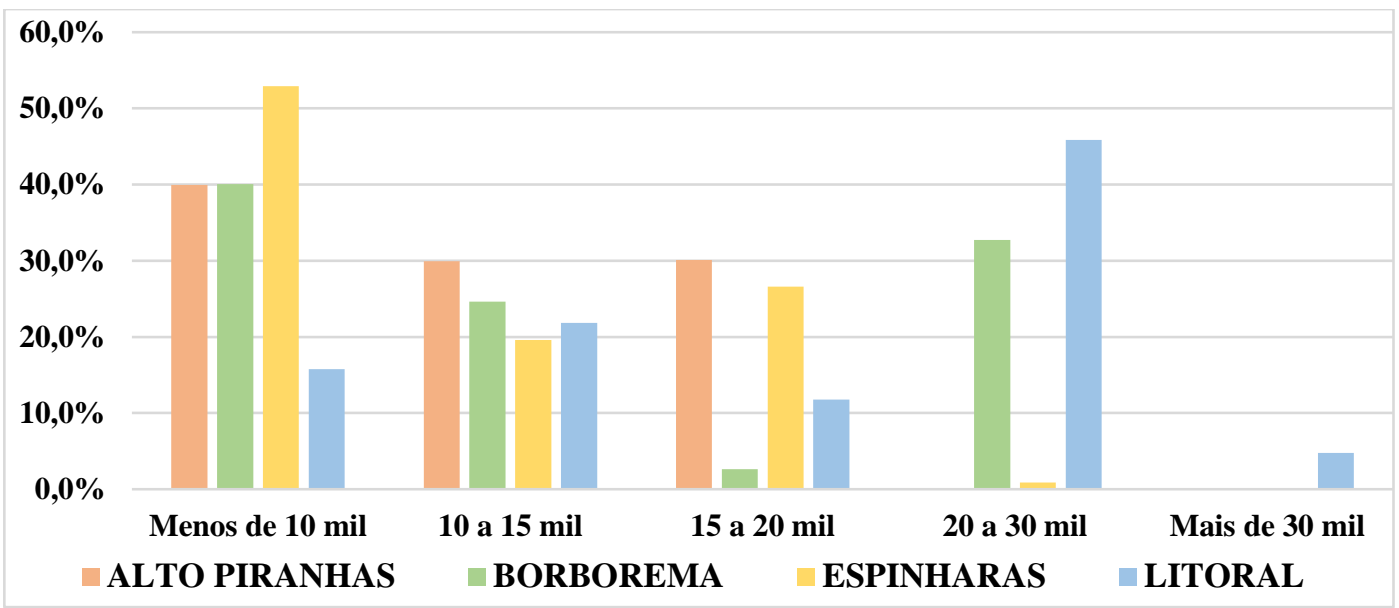

Fonte: Autores com base em dados do Estudo Técnico (2021).

O IDHM, é um índice composto por indicadores de renda, educação e longevidade, varia de 0 a 1 e quanto mais próximo de 1, mais alto é o desenvolvimento humano do município, microrregião, estado, país ou continente a ser analisado. Esse índice apresenta aspectos socioeconômicos mais abrangentes, que permitem compreender melhor o perfil da população de cada microrregião de água e esgoto da Paraíba. Na comparação entre as microrregiões, é possível identificar que, na Microrregião do Litoral, a população com IDHM alto corresponde a 47,7\%; na Borborema corresponde a 32,2\%, em Espinharas apenas 23,9\% da população possui IDHM alto, e em Alto Piranhas não há municípios com IDHM alto, portanto, não há população dentro desse perfil (Gráfico 4).

A Microrregião de Alto Piranhas, por outro lado, apresenta o maior percentual de população com IDHM médio, com $56,6 \%$, e o restante da população, cerca de 43,4\%, reside em municípios que apresentam IDHM baixo. A Borborema tem $27,1 \%$ da população em municípios com IDHM médio e 40,7\% em municípios com IDHM baixo. Espinharas apresenta 32,8\% da população situada em municípios que possuem IDHM médio e cerca de 43,3\% da população em municípios com IDHM baixo. A Microrregião do Litoral apresenta 20,3\% da população em municípios com IDHM médio e 32,0\% em municípios com IDHM baixo.

Gráfico 4: IDHM da população (2010) por microrregiões.

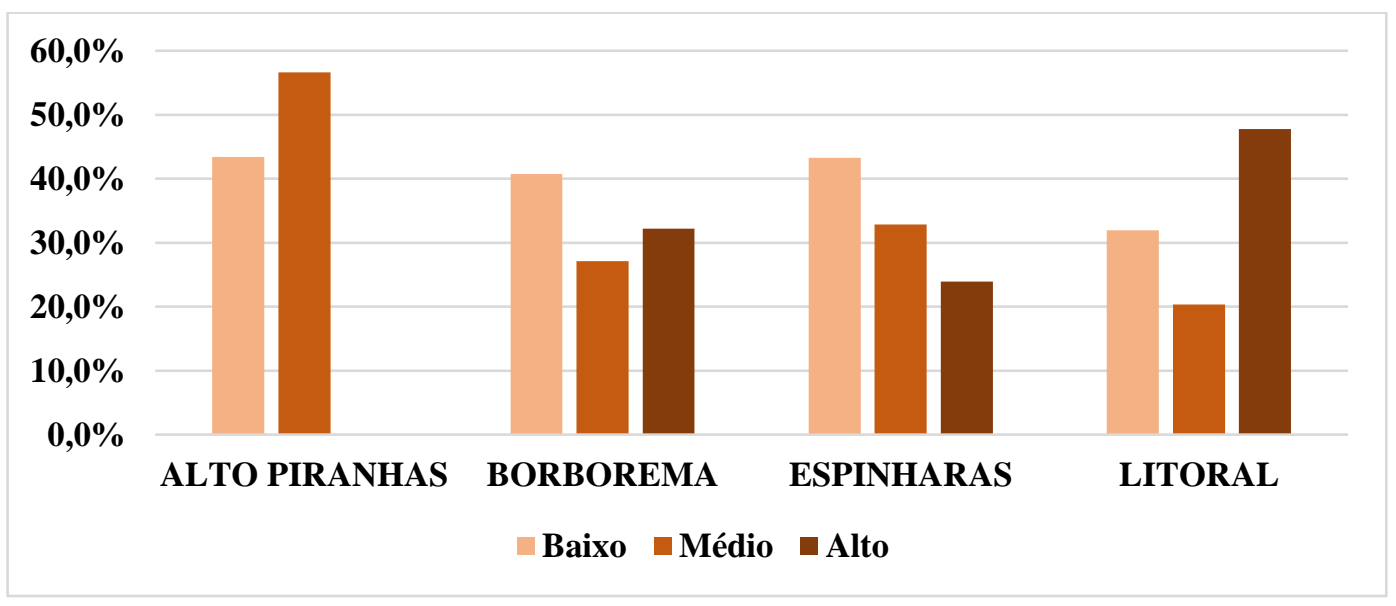

Fonte: Autores, com base em dados do Estudo Técnico (2021), 2021. 


\section{Aspectos Operacionais}

Em relação aos aspectos operacionais do saneamento nas Microrregiões de Água e Esgoto da Paraíba, serão abordados os dados mais recentes do SNIS (2019), que tratam sobre os prestadores e o atendimento total de água e esgoto nos municípios dessas microrregiões. O prestador regional é a CAGEPA, que atende cerca de 200 municípios da Paraíba, e é responsável pelo processo de captação da água bruta nos mananciais, pelo tratamento dessa água para garantir que esteja dentro dos padrões de potabilidade, exigidos pelas normas vigentes, e distribuição para que essa água tratada chegue aos domicílios ligados aos sistemas de abastecimento. Os prestadores locais são os que a titularidade de serviços de água e/ou esgoto estão sob governança local, seja por administração pública direta da Prefeitura Municipal ou por Autarquia, como Serviço Autônomos de Água e Esgoto (SAAE) e Departamento de Água e Esgoto (DAE).

Na Figura 6, é possível observar quais são os municípios paraibanos atendidos pela CAGEPA e quais os atendidos por prestadores locais. Em Alto Piranhas, são três os municípios que não são atendidos pela CAGEPA, aproximadamente $8 \% \mathrm{em}$ relação ao total de municípios da microrregião. Em Borborema são 8, ou seja, aproximadamente $10 \%$ dos municípios dessa microrregião são atendidos por prestadores locais. Em Espinharas, são 5, o equivalente a cerca de 11\%. No Litoral, 7 municípios não são atendidos pela CAGEPA e sim por prestadores locais, isso corresponde a, aproximadamente, $13 \%$ dos municípios da microrregião. Nota-se a relevância do prestador regional para o atendimento de quase $90 \%$ dos municípios paraibanos e a sua contribuição para a disponibilização dos dados sobre a prestação dos serviços de água e esgoto nesses municípios, através do SNIS, que é essencial para o desenvolvimento do setor e para a garantia do livre acesso aos dados sobre o saneamento.

Figura 6: Prestadores de serviço de água e esgoto nos municípios paraibanos.

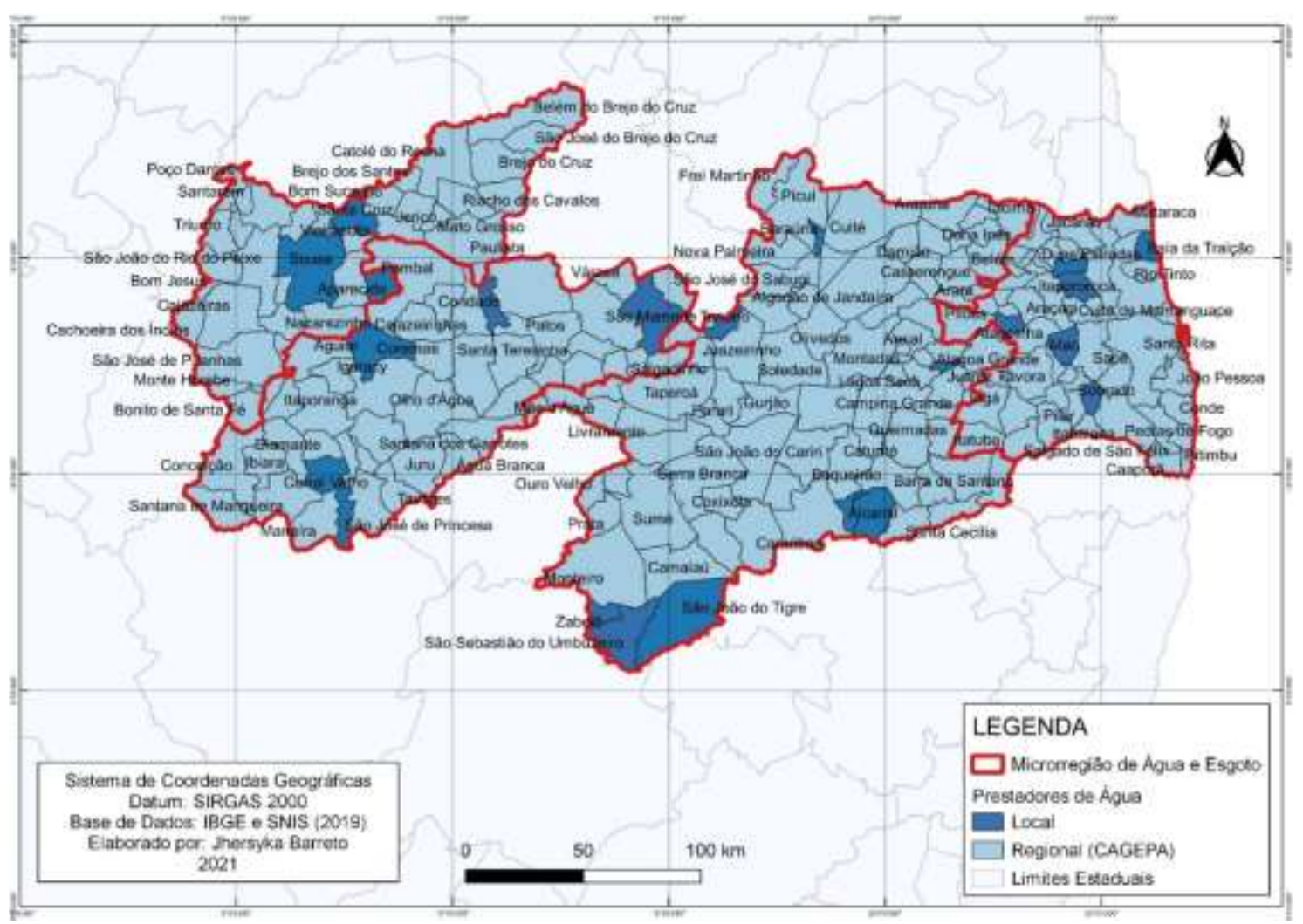

Fonte: Autores, a partir de dados disponíveis no SNIS (2019).

Além disso, a empresa estatal, CAGEPA, por possuir abrangência regional e atuar na maioria dos municípios paraibanos, consegue viabilizar o abastecimento de água mesmo nos municípios deficitários, por intermédio dos subsídios cruzados, que são uma forma de garantir o acesso aos serviços de saneamento para aqueles que não possuem capacidade de pagamento. As 
mudanças nas legislações do setor de saneamento, que foram abordadas na introdução, dificultam a atuação das empresas públicas nos estados, com a obrigatoriedade das licitações e abertura para a livre concorrência nos serviços de água e esgotamento sanitário. Com as mudanças recentes, ainda não se sabe o que ocorrerá com as empresas estatais de água e esgotamento sanitário, como a CAGEPA, e como ficarão os municípios deficitários do país, que dependem dos subsídios cruzados aplicados pelas estatais para garantir a prestação dos serviços, sobretudo de abastecimento de água, nesses municípios.

Os índices de atendimento total de água (IN055) e de atendimento total de esgoto referidos aos municípios atendidos por água (IN056) estão disponíveis no SNIS (2019). Esses índices retratam a realidade do atendimento de cada municípios por intermédio dos prestadores locais e/ou regionais de água e esgoto, exceto daqueles que não disponibilizaram os dados. Dessa forma, é possível visualizar a situação das microrregiões de água e esgoto em relação ao percentual de atendimento dos seus municípios (Figuras 7 e 8 ).

Em relação ao percentual do atendimento total de água dos municípios por microrregião, a Microrregião da Borborema destaca-se por apresentar a pior situação quando comparada às demais microrregiões. É a que possui o maior percentual de municípios com o índice de abastecimento total entre 0 e $20 \%$, com cerca de $18 \%$ dos seus municípios nessa situação, e o menor percentual de municípios com atendimento total entre 80 e 100\%, sendo apenas 7\%. Espinharas é a que apresenta a melhor situação, com apenas $6,5 \%$ dos municípios com índice de atendimento entre 0 e $20 \%$, e $24 \%$ dos municípios com atendimento total de água acima de 80\%. Alto Piranhas e Litoral apresentam uma realidade intermediária comparada com as demais (Tabela $1)$.

Tabela 1: Distribuição dos municípios das microrregiões (\%) por faixa de atendimento total de água.

\begin{tabular}{l|c|c|c|c|c|c}
\multicolumn{1}{c|}{ MICRORREGIÃO } & $\mathbf{0 - 2 0 \%}$ & $\mathbf{2 0 - 4 0 \%}$ & $\mathbf{4 0 - 6 0 \%}$ & $\mathbf{6 0}-\mathbf{8 0} \%$ & $\mathbf{8 0}-\mathbf{1 0 0} \%$ & Sem Dados \\
\hline ALTO PIRANHAS & 10,5 & 8,0 & 31,6 & 31,6 & 13,0 & 5,3 \\
\hline BORBOREMA & 18,0 & 18,0 & 20,0 & 31,0 & 7,0 & 6,0 \\
\hline ESPINHARAS & 6,5 & 6,5 & 26,0 & 30,5 & 24,0 & 6,5 \\
\hline LITORAL & 10,9 & 12,7 & 21,8 & 27,3 & 20,0 & 7,3
\end{tabular}

Fonte: Autores, com base em dados do SNIS (2019).

Os dados de atendimento total de água por faixa de atendimento possibilitam que sejam identificados quais são os municípios com os piores, os intermediários e os melhores percentuais de atendimento em cada microrregião (Figura 7). Tais dados são relevantes para o desenvolvimento das metas para o Plano Regional de Saneamento Básico (PRSB), que, de acordo com o art. 17 da Lei 14.026 (2020), prevalecerão em relação ao que constar nos Planos Municipais de Saneamento Básico (PMSB), caso os municípios das Microrregiões possuam. Dessa forma, os municípios com os menores percentuais de atendimento total de água deveriam ser incluídos no PRSB como prioritários para investimentos na expansão da rede de abastecimento de água para que as metas regionais de cobertura do sistema de abastecimento de água não sejam elevadas a partir da concentração de investimentos em áreas que possuem o atendimento mais elevado, o que aumentaria as disparidades entre os municípios em relação aos serviços públicos de saneamento. 
Figura 7: Índice de atendimento total de água nos municípios paraibanos.

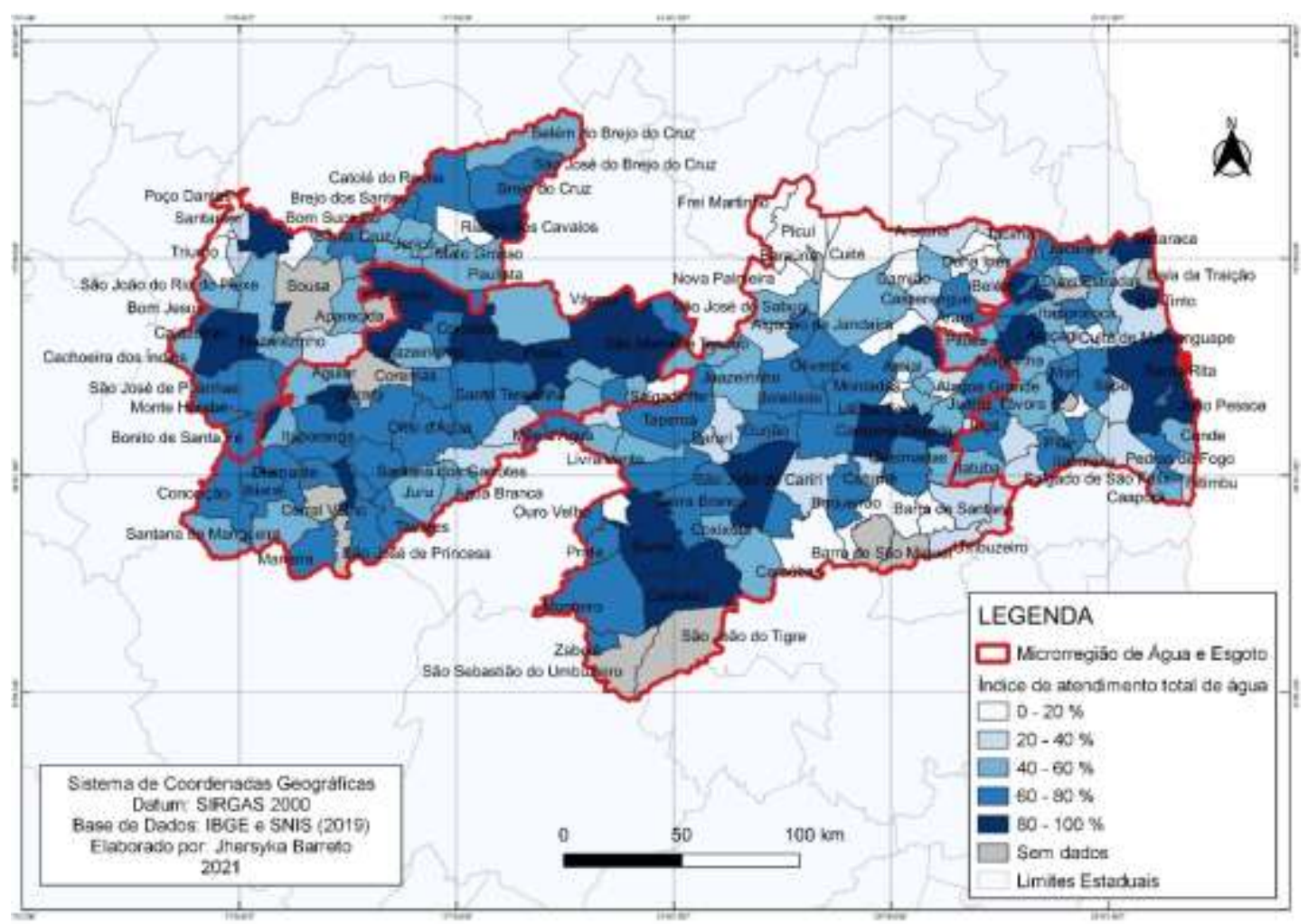

Fonte: Autores, a partir de dados disponíveis no SNIS (2019).

Os índices de atendimento total de água e de esgoto dos municípios possibilitam que sejam calculados os valores médios desses índices por microrregiões. As microrregiões com as melhores médias de atendimento de esgoto são a do Litoral e a da Borborema, com médias de 5,2\% e 4,7\%, respectivamente. A situação de Alto Piranhas e de Espinharas são ainda piores, com médias de 2,6\% e 1,5\%, respectivamente. Mas, quando se trata de atendimento total de esgoto, a realidade dos municípios e das microrregiões paraibanas é crítica (Tabela 2). O déficit dos serviços de esgotamento sanitário está presente em todos os municípios paraibanos e reflete nas médias das microrregiões.

Tabela 2: Média do atendimento total de água e esgoto por Microrregião da Paraíba.

\begin{tabular}{l|c|c} 
MICRORREGIÃO & ÁGUA (\%) & ESGOTO (\%) \\
\hline ALTO PIRANHAS & 54,5 & 2,6 \\
\hline BORBOREMA & 44,9 & 4,7 \\
\hline ESPINHARAS & 58,0 & 1,5 \\
\hline LITORAL & 53,8 & 5,2
\end{tabular}

Fonte: Autores, com base em dados do SNIS (2019).

Os percentuais de atendimento total de água e esgoto limitam-se aos dados que foram disponibilizados pelos municípios, sendo assim, esses resultados podem variar para mais ou para menos em relação ao cálculo com os dados de todos os municípios por Microrregião. Quanto maior a quantidade de municípios que não disponibilizaram os seus dados no SNIS, em 2019, e dos municípios com os piores índices de atendimento desses serviços, a média da microrregião tende a cair. 


\subsection{Cenários Distintos de Disponibilidade Hídrica das Microrregiões}

A situação das adutoras de abastecimento de água nos municípios paraibanos foi avaliada pela AESA, em 2020, que classificou esses municípios de acordo com os seguintes critérios: sem informação; baixa garantia hídrica; ampliação do sistema produtor; e abastecimento satisfatório. Esses municípios foram organizados com base na divisão das Microrregiões de Água e Esgoto da Paraíba para analisar a situação atual de cada microrregião em relação a situação das adutoras de abastecimento de água de seus municípios (Gráfico 5).

Gráfico 5: Situação das adutoras de abastecimento de água.

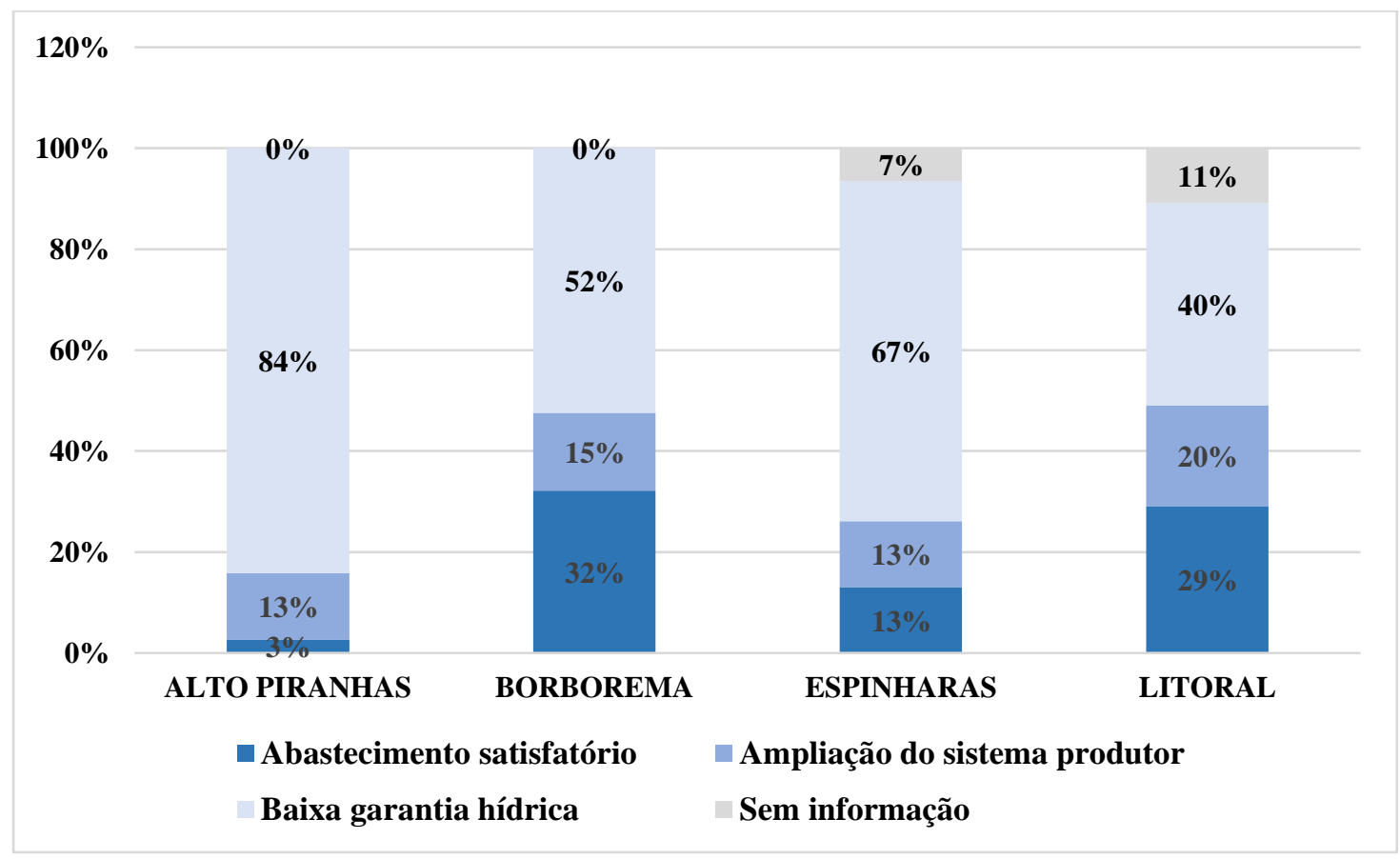

Fonte: Autores com base em dados da AESA (2020).

No caso da Microrregião do Alto Piranhas, apenas 3\% dos municípios apresentam abastecimento satisfatório, outros $13 \%$ estão em processo de ampliação do sistema produtor, enquanto $84 \%$ possuem baixa garantia hídrica. Na Borborema, $32 \%$ dos municípios apresentam abastecimento satisfatório, $15 \%$ estão em ampliação do sistema produtor e $52 \%$ possuem baixa garantia hídrica. Espinharas possui $13 \%$ dos municípios com abastecimento satisfatório e o mesmo percentual para os municípios com ampliação do sistema produtor, $64 \%$ dos municípios estão em situação de baixa garantia hídrica e 7\% estão sem informação. A Microrregião do Litoral possui $29 \%$ dos municípios classificados como abastecimento satisfatório, $20 \%$ em ampliação do sistema produtor e $40 \%$ dos municípios com baixa garantia hídrica e outros $11 \%$ sem informação. Ou seja, essa microrregião é a que possui o menor percentual de municípios com baixa demanda hídrica, além disso, a soma do percentual de municípios com abastecimento satisfatório e em ampliação do sistema produtor é maior que a das outras microrregiões. Por outro lado, Alto Piranhas é a microrregião que apresenta a situação mais crítica quanto a baixa garantia hídrica dos municípios, seguida por Espinharas e Borborema, que também apresentam cenários climáticos desfavoráveis em relação a garantia hídrica.

Os dados de monitoramento dos açudes da Paraíba, disponibilizados pela AESA, foram organizados por microrregiões de água e esgoto para possibilitar a comparação da capacidade hídrica total e do volume total disponível nos açudes de cada microrregional nos anos de 2015, 2017, 2019 e 2021. Além disso, foram identificados alguns dos mananciais de maior capacidade hídrica das microrregionais durante esses anos e a variação de percentual do volume desses açudes para analisar os diferentes cenários climáticos que afetam a disponibilidade hídrica das microrregiões de água e esgoto da Paraíba. 
A Microrregião de Espinharas destaca-se em relação a capacidade máxima dos seus açudes, pois dos 10 maiores açudes paraibanos, $50 \%$ estão situados nessa microrregião, que são: Coremas $\left(1^{\circ}\right)$ e Mãe D’Água $\left(2^{\circ}\right)$, que ficam no município de Coremas e são, respectivamente, o primeiro e o segundo maior açude paraibano; Saco $\left(6^{\circ}\right)$, que fica em Nova Olinda; Cachoeira dos Cegos $\left(8^{\circ}\right)$, situado em Catingueira; e Jenipapeiro $\left(9^{\circ}\right)$, que fica no município de Olho D’Água. Alto Piranhas tem dois açudes dentre os maiores do Estado: Engenheiro Ávidos $\left(4^{\circ}\right)$ e Lagoa do Arroz $\left(7^{\circ}\right)$, que ficam em Cajazeiras. Borborema também possui dois açudes nessa lista, são eles: Epitácio Pessoa $\left(3^{\circ}\right)$, que fica em Boqueirão, e Cordeiro $\left(10^{\circ}\right)$, que fica no Congo. A Microrregião do Litoral possui apenas um açude nessa lista: Acauã (5º ), que fica no município de Itatuba (Gráfico 6).

Gráfico 6: Capacidade máxima dos açudes das Microrregiões $\left(\mathrm{m}^{3}\right)$.

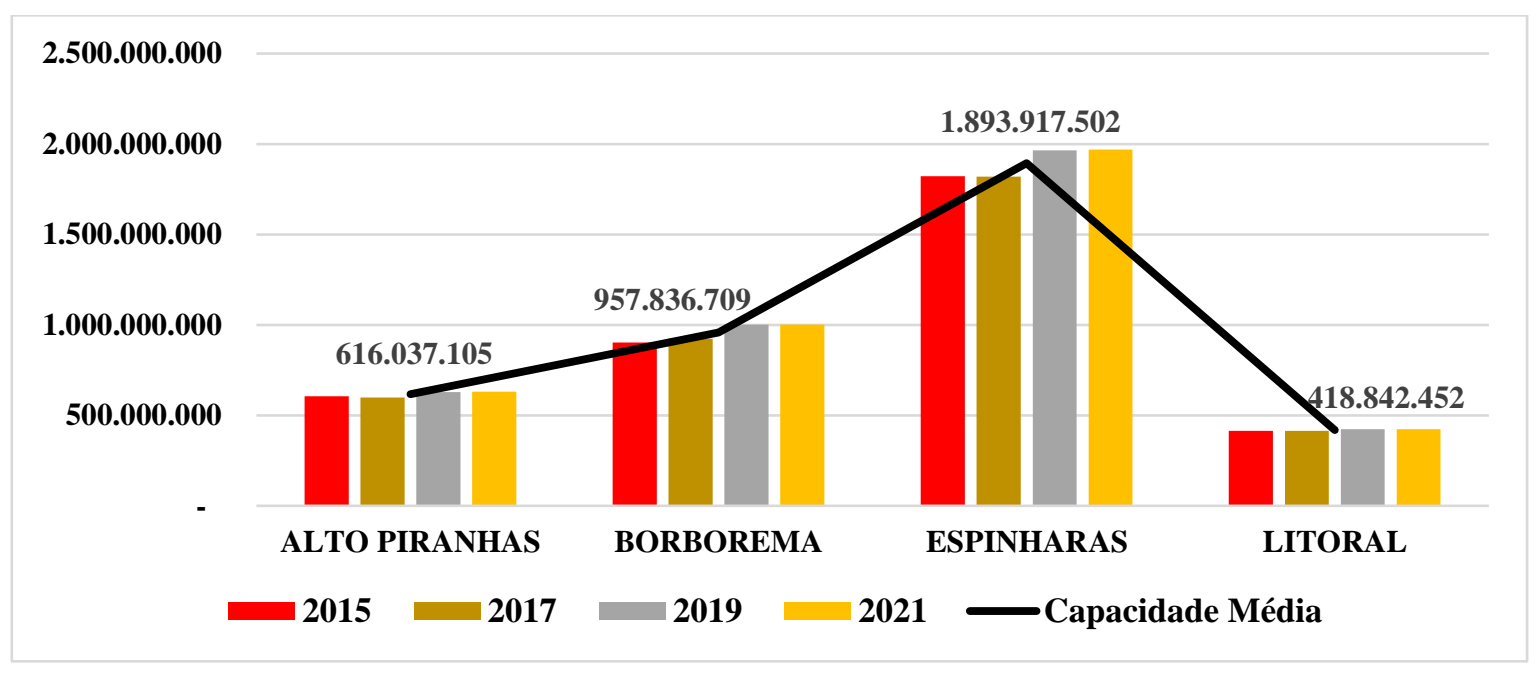

Fonte: Autores, com base em dados da AESA (2021).

Em relação ao volume total dos açudes, foram utilizados os dados de junho de cada ano, provenientes do monitoramento da AESA (Gráfico 7). Os dados dos açudes foram distribuídos em planilhas de acordo com a sua localização em relação as microrregiões de água e esgoto da Paraíba para que fosse possível compará-las. Nota-se que Alto Piranhas, Borborema e Espinhares apresentam variações semelhantes do volume total de água nos açudes ao longo dos anos, o que demonstra que essas microrregiões possuem, também, algumas similaridades entre si em relação ao cenário climático e hídrico ao qual estão inseridas. A Microrregião do Litoral se diferencia das demais por apresentar uma baixa variação no volume total dos seus açudes ao longo dos anos e uma média do volume total mais elevada, mesmo com a menor capacidade máxima em relação aos açudes das outras Microrregiões. A média de Alto Piranhas, Borborema e Espinharas foi de 23\%, 21\% e 27\%, respectivamente, em relação aos anos de 2015, 2017, 2019 e 2021. Já a média do Litoral foi de 38\%, nesse mesmo período. 
Research, Society and Development, v. 10, n. 10, e117101018513, 2021

(CC BY 4.0) | ISSN 2525-3409 | DOI: http://dx.doi.org/10.33448/rsd-v10i10.18513

Gráfico 7: Volume total dos açudes das Microrregiões.

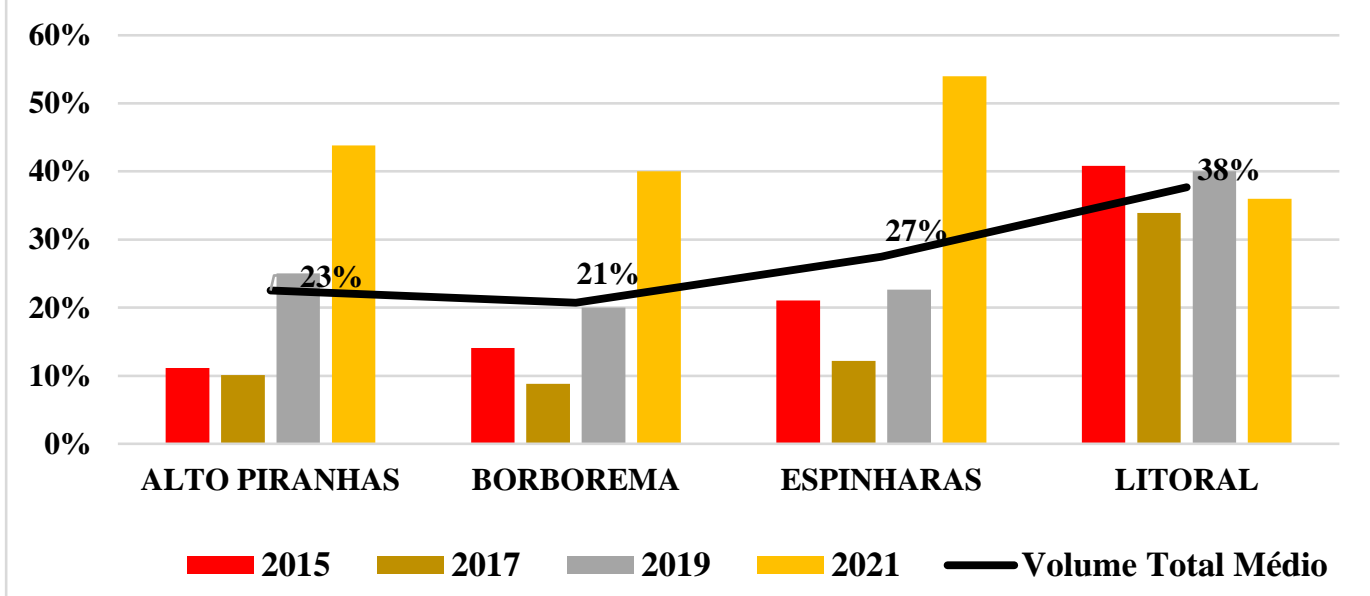

Fonte: Autores, dados da AESA (junho/ANO) (2021).

Alguns aspectos climáticos, como índice pluviométrico e índice de evapotranspiração, geológicos, como tipos de solos e existência de aquíferos subterrâneos e outros aspectos ambientais, como tipos de mananciais (rios permanentes e intermitentes), interferem diretamente na disponibilidade hídrica das microrregiões. Esses aspectos não serão abordados em sua totalidade, pois não é esse o objeto do presente estudo, mas, em razão da influência direta e indireta nos cenários hídricos dos municípios paraibanos, a média pluviométrica anual foi incluída para ilustrar a realidade das microrregiões de água e esgoto quanto a incidência de precipitações (Figura 8).

Figura 8: Média pluviométrica anual dos municípios paraibanos.

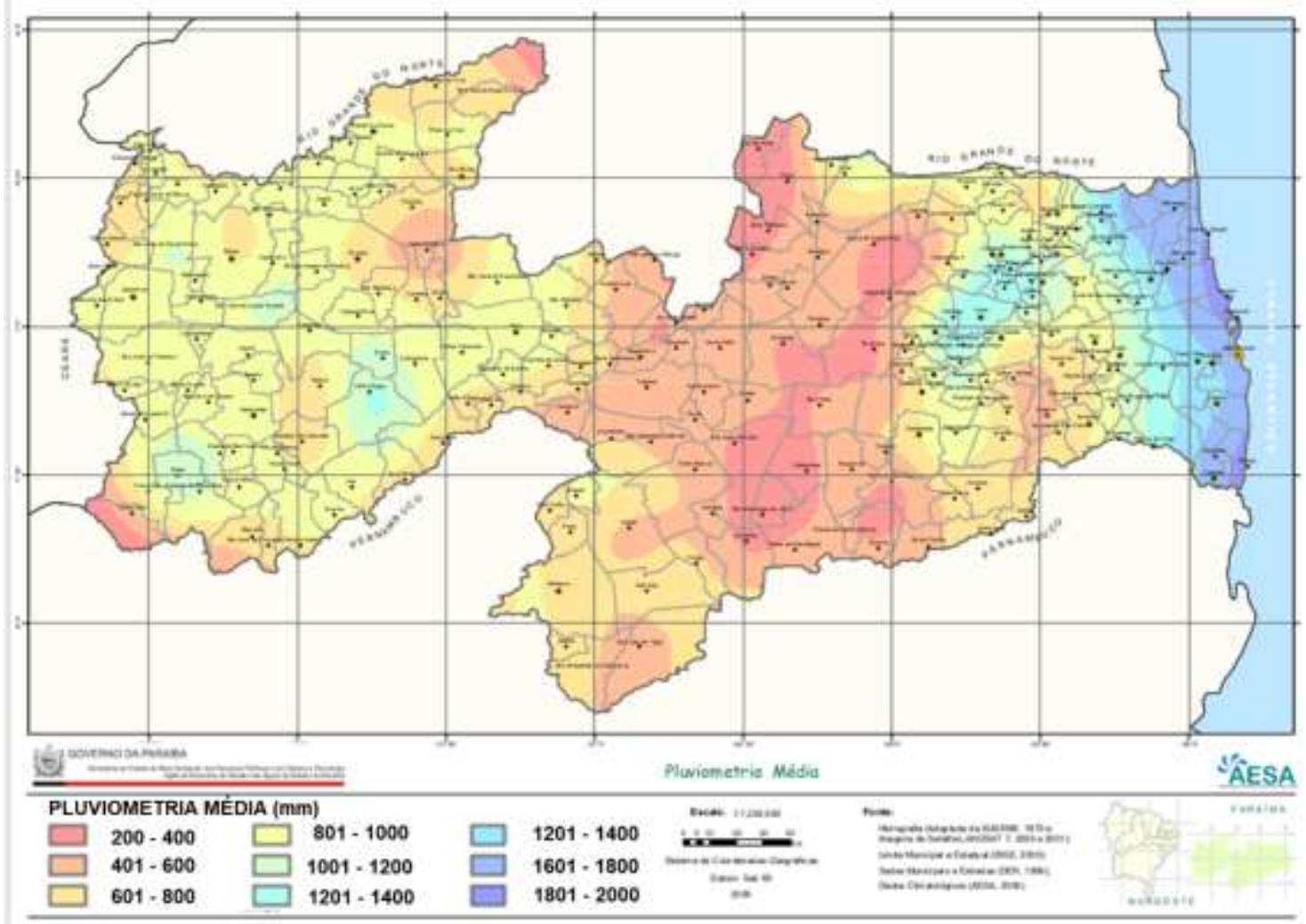

Fonte: Mapa de Pluviometria Média (2006), Geo Portal da AESA (2021a).

Os índices médios da pluviometria anual são representados no mapa acima pela variação de cores, como mostra na 
legenda. Os menores índices de pluviometria média (entre 200 e 1000 milímetros) afetam áreas da Caatinga, que são conhecidas como Semiárido Paraibano, e, também, áreas de transição entre o Bioma da Mata Attântica e da Caatinga. Os índices de pluviometria média mais elevados (acima de 100 milímetros) do Estado são mais comuns em áreas situadas no Bioma da Mata Atlântica e no Brejo Paraibano, e ocorrem, de forma pontual, em pequenas áreas do Semiárido (Figura 8).

Nota-se que, a Microrregião do Litoral, por exemplo, apresenta condições climáticas mais favoráveis para a manutenção do volume total dos mananciais: com os maiores índices pluviométricos do Estado (como podem ser observados na Figura 8), menor evapotranspiração, solos mais permeáveis, existência de aquíferos subterrâneos e de rios permanentes, pois abrange, predominantemente, áreas situadas no Bioma da Mata Attântica e em áreas do Ecótono, que é a transição entre o Bioma da Mata Atlântica e o Bioma da Caatinga. Enquanto as demais microrregiões apresentam, predominantemente, áreas semiáridas, que são caracterizadas por baixos índices pluviométricos (entre 200 e $800 \mathrm{~mm}$, podendo chegar a $1000 \mathrm{~mm}$ em períodos mais chuvosos), baixa permeabilidade do solo, elevadas taxas de evapotranspiração, baixo potencial hídrico subterrâneo e superficial, com rios intermitentes, que são características típicas do Bioma da Caatinga, com exceção de algumas áreas pontuais, que apresentam índices pluviométricos mais elevados.

Em um Estado como a Paraíba, que tem os açudes como a fonte hídrica predominante para o abastecimento de água dos municípios, é indispensável discutir e analisar a variação do volume total de alguns dos mananciais de maior capacidade hídrica de cada microrregião (Quadros 5, 6, 7 e 8). Além disso, não tem como deixar de fora o Projeto de Integração do Rio São Francisco (PISF), que já tem influenciado nas variações de volumes dos açudes beneficiados por esse projeto. O PISF, conhecido também como Transposição do Rio São Francisco, visa interligar a Bacia Hidrográfica do Rio São Francisco com Bacias Hidrográficas do Nordeste Setentrional, que abrangem parcialmente os estados: Pernambuco, Paraíba, Rio Grande do Norte e Ceará. Na Paraíba, algumas etapas do PISF seguem em andamento, o projeto está dividido em dois eixos: Eixo Norte, que leva águas do Rio São Francisco para a Bacia Hidrográfica do Rio Piranhas, e Eixo Leste, que leva águas do Rio São Francisco para a Bacia Hidrográfica do Rio Paraíba (Relatório de Impacto Ambiental [RIMA], 2004).

Os açudes/barragens que serão beneficiados pelo PISF estão distribuídos por todas as microrregiões de água e esgoto da Paraíba. Em Alto Piranhas, o Aç. Engenheiro Ávidos, o Aç. Lagoa do Arroz e o Aç. São Gonçalo receberão águas do Rio São Francisco, através do Eixo Norte, que, também, beneficiará o Aç. Coremas - Mãe D’Água, na Microrregião de Espinharas. Na Borborema, já foram beneficiados, através dos ramais do Eixo Leste, o Aç. de Poções, o Aç. Camalaú e o Aç. Epitácio Pessoa, que recebem águas do Rio São Francisco desde 2017. Na Microrregião do Litoral, os açudes beneficiados são Aç. Acauã (Argemiro de Figueiredo), em Itatuba, e Aç. Araçagi, que fica no município de mesmo nome (RIMA, 2004).

Em relação ao volume total, a média anual dos açudes de Alto Piranhas, em 2015 e 2017, foram semelhantes, sendo de 11,6\% e 12,0\%, respectivamente. Houve aumento do volume médio total nos açudes: Aç. Lagoa do Arroz, situado na Bacia Hidrográfica do Peixe, em Cajazeiras, e Aç. São Gonçalo, na Região do Alto Curso do Rio Piranhas, em Sousa. E redução do volume médio, nos seguintes açudes: Aç. Engenheiro Ávidos, que fica na Região do Alto Curso do Rio Piranhas, em Cajazeiras, Aç. Baião, na Região do Médio Curso do Rio Piranhas, em São José do Brejo Cruz, e Aç. Capivara, em Uiraúna, situado na Bacia Hidrográfica do Peixe. Entre 2017 e 2019, houve aumento do volume total na maioria dos açudes, a média anual variou de 12\% para 26,6\%, em 2019, com exceção do Aç. Capivara, todos os açudes apresentaram aumentos significativos em seus respectivos volumes hídricos, devido ao aumento das precipitações. Em 2021, todos os açudes apresentaram elevação em seus volumes hídricos, com destaque para o Açude Lagoa do Arroz, que apresentou 16,2\%, em 2019, e 46,3\%, em 2021 (Quadro 3). 
Quadro 3: Variação do volume total dos açudes de maior capacidade hídrica da Microrregião do Alto Piranhas.

\begin{tabular}{|l|l|r|r|r|r|}
\hline \multirow{2}{*}{ Açude } & \multirow{2}{*}{ Município } & \multicolumn{4}{|l|}{ Volume Total (\%) } \\
\cline { 2 - 6 } & & $\mathbf{2 0 1 5}$ & $\mathbf{2 0 1 7}$ & $\mathbf{2 0 1 9}$ & $\mathbf{2 0 2 1}$ \\
\hline Engenheiro Ávidos & Cajazeiras & 9,4 & 5,0 & 21,4 & 38,7 \\
\hline Lagoa do Arroz & Cajazeiras & 8,9 & 12,6 & 16,2 & 46,3 \\
\hline Baião & S. J. do Brejo Cruz & 18,7 & 12,4 & 42,1 & 67,5 \\
\hline São Gonçalo & Sousa & 8,3 & 26,2 & 50,6 & 67,3 \\
\hline Capivara & Uiraúna & 12,8 & 3,6 & 2,6 & 6,4 \\
\hline Média & & 11,6 & 12,0 & 26,6 & 45,2 \\
\hline
\end{tabular}

Fonte: Autores, com base em dados da AESA (2021).

Até 2017, a Paraíba, atravessava um longo período de seca, que comprometeu a segurança hídrica e o abastecimento de municípios paraibanos situados nas áreas mais críticas, devido aos baixos índices pluviométricos que resultaram na baixa disponibilidade hídrica dos mananciais. A partir de março de 2017, as águas do PISF, chegaram no território da Paraíba, por meio do Eixo Leste, que levou água para a Microrregião da Borborema. As águas chegaram na Região do Alto Curso do Rio Paraíba, em Monteiro, onde fica o Açude de Poções, seguiram para o Açude Camalaú, que fica no município de mesmo nome, e, 41 dias após chegarem na Paraíba, no dia 19 de abril, chegaram ao Açude Epitácio Pessoa, em Boqueirão, que se encontrava em seu volume morto, o que resultou, progressivamente, no aumento do volume médio desse manancial (G1, 2017; AESA, 2021a).

Na Microrregião da Borborema, no período de 2015 a 2017, houve uma redução da média do volume total dos açudes analisados, que foi de 12,3\%, em 2015, para 8\%, em 2017. Em 2019, nota-se que houve um aumento da média desse volume para 12,4\%, com destaque para o aumento significativo do volume total de águas no Aç. Epitácio Pessoa e redução do volume de dois açudes, Aç. Camalaú e Aç. Sumé. Em 2021, todos os açudes apresentaram elevação do volume hídrico, a média do volume anual foi de 58,3\%, com destaque para o Aç. de Poções, que estava com um volume de 6,8\%, em 2019, e foi para 93,5\% de sua capacidade total, em 2021 (Quadro 4).

Quadro 4: Variação do volume total dos açudes de maior capacidade hídrica da Microrregião da Borborema.

\begin{tabular}{|l|l|r|r|r|r|}
\hline \multirow{2}{*}{ Açude } & \multirow{2}{*}{ Município } & \multicolumn{4}{|l|}{ Volume Total (\%) } \\
\cline { 3 - 6 } & & $\mathbf{2 0 1 5}$ & $\mathbf{2 0 1 7}$ & $\mathbf{2 0 1 9}$ & $\mathbf{2 0 2 1}$ \\
\hline Epitácio Pessoa & Boqueirão & 17,9 & 6,8 & 25,0 & 43,3 \\
\hline Camalaú & Camalaú & 21,0 & 14,1 & 11,2 & 64,5 \\
\hline Cordeiro & Congo & 3,7 & 0,03 & 13,2 & 68,6 \\
\hline Poções & Monteiro & 2,0 & 6,4 & 6,8 & 93,5 \\
\hline Sumé & Sumé & 17,0 & 13,0 & 5,8 & 21,4 \\
\hline Média & & 12,3 & 8,0 & 12,4 & 58,3 \\
\hline
\end{tabular}

Fonte: Autores, com base em dados da AESA (2021).

Na Microrregião de Espinharas, de 2015 para 2017, houve redução do volume total de água nos açudes analisados, que estão situados na Bacia Hidrográfica do Rio Piancó, a média anual foi de 23,0\% para 14,1\%. O Aç. Mãe D’Água foi o que apresentou a maior queda de volume hídrico, que foi de 20,8\% para 5,3\% da capacidade total desse açude. Em 2019, a média foi de 24,6\%, e, em 2021, elevou-se para 55,0\%. Nesse período, todos os açudes apresentaram aumento do volume total, o Aç. Cachoeira dos Cegos, em Catingueira, foi o que teve a maior elevação do volume, depois o Aç. Mãe D’Água e o Aç. Coremas, 
localizados em Coremas (Quadro 5).

Quadro 5: Variação do volume total dos açudes de maior capacidade hídrica da Microrregião de Espinharas.

\begin{tabular}{|l|l|r|r|r|r|}
\hline \multirow{2}{*}{ Açude } & Município & Volume Total (\%) & & \\
Cachoeira dos Cegos & Catingueira & $\mathbf{2 0 1 5}$ & $\mathbf{2 0 1 7}$ & $\mathbf{2 0 1 9}$ & $\mathbf{2 0 2 1}$ \\
\hline Coremas & Coremas & 18,0 & 21,4 & 50,0 & 74,1 \\
\hline Mãe D’Água & Coremas & 20,8 & 5,3 & 16,8 & 53,2 \\
\hline Saco & Nova Olinda & 25,6 & 20,6 & 30,4 & 53,3 \\
\hline Jenipapeiro (Buiú) & Olho D’Água & 23,6 & 14,6 & 15,2 & 54,4 \\
Média & & 23,0 & 14,1 & 24,6 & 40,3 \\
\hline
\end{tabular}

Fonte: Autores, com base em dados da AESA (2021).

A Microrregião do Litoral, diferencia-se das demais por apresentar condições climáticas mais favoráveis, que possibilitam uma maior disponibilidade hídrica em seus mananciais superficiais e subterrâneos. $\mathrm{O}$ açude com a segunda maior capacidade máxima de volume hídrico, Aç. Saulo Maia, situado em Areia, não teve os seus volumes incluídos nos dados de monitoramento da AESA em 2015 e 2017, por isso ele não foi incluído entre os cinco açudes que compõem a média anual da microrregião. Em 2015, a média foi de 59,1\%, e aumentou para 61,4\%, em 2017, sendo que apenas dois açudes, que estão em áreas com menores índices pluviométricos, apresentaram redução do seu volume, são eles: Aç. Araçagi, situado em município de mesmo nome, e o Aç. Acauã, em Itatuba. Em 2019, a média anual do volume total foi de 75,2\%, com aumento do volume em todos os açudes. Por outro lado, em 2021, a média caiu para 60,4\%, com a redução do volume da maioria dos mananciais, com exceção do Aç. Acauã e do Aç. Tauá, em Cuitegi (Quadro 6). Em janeiro de 2021, a água do Rio São Francisco chegou ao Canal Acauã-Araçagi (AESA, 2021c).

Quadro 6: Variação do volume total dos açudes de maior capacidade hídrica da Microrregião do Litoral.

\begin{tabular}{|c|c|c|c|c|c|}
\hline \multirow{2}{*}{ Açude } & \multirow{2}{*}{ Município } & \multicolumn{4}{|c|}{ Volume Total (\%) } \\
\hline & & 2015 & 2017 & 2019 & 2021 \\
\hline Araçagi & Araçagi & 101,6 & 83,1 & 101,1 & 77,4 \\
\hline Gramame/ Mamuaba & Conde & 83,0 & 101,6 & 102,2 & 78,3 \\
\hline Tauá & Cuitegi & 12,5 & 33,2 & 63,9 & 65,2 \\
\hline Acauã & Itatuba & 16,0 & 4,8 & 6,0 & 13,2 \\
\hline São Salvador & Sapé & 82,4 & 84,1 & 102,7 & 68,0 \\
\hline \multicolumn{2}{|l|}{ Média } & 59,1 & 61,4 & 75,2 & 60,4 \\
\hline Saulo Maia* & Areia & - & - & 80,0 & 51,4 \\
\hline
\end{tabular}

* Aç. Saulo Maia, em Areia, não foi incluído na média por ausência de dados. Fonte: Autores, com base em dados da AESA (2021).

Nota-se que, mesmo nos anos de baixos índices pluviométricos, como entre 2015 e 2017, a Microrregião do Litoral mantém médias anuais superiores a 50\%. Enquanto as demais Microrregiões, nesse mesmo período, apresentam médias inferiores a $25 \%$ e apresentam açudes que chegam a atingir o volume morto, nos cenários mais críticos de baixa disponibilidade e da má distribuição de água, que pode comprometer a segurança hídrica no Alto Piranhas, em Borborema e em Espinharas. A Microrregião da Borborema destaca-se por possuir a maior quantidade de municípios em áreas com os menores índices 
pluviométricos da Paraíba, o que pode resultar em crises de abastecimento de água nos períodos de seca. Diante dessa realidade, qual a razão de municípios com mananciais, como Areia e Itatuba, pertencerem a Microrregião do Litoral e não a da Borborema?

\subsection{Sustentabilidade Econômico-financeira das Microrregiões de Água e Esgoto da Paraíba}

O indicador de desempenho financeiro (IN012) do SNIS, composto por FN001 - que é a soma de todas as receitas operacionais diretas FN002, FN003, FN007 e FN038 - dividido por FN017, que corresponde às despesas totais com os serviços (DTS) foi adotado para ser aplicado no estudo de viabilidade econômico-financeira das Microrregiões de água e esgoto da Paraíba.

A Microrregião de Alto Piranhas não apresenta sustentabilidade econômico-financeira de acordo com o indicador de desempenho financeiro (IN012), que foi inferior a 100\%. Em 2015, esse indicador foi de 68\%, sendo melhor em 2017, igual a $76 \%$, e chegou a $93 \%$, em 2019, com média equivalente a $79 \%$. Na Borborema, o indicador de desempenho financeiro apresentou percentuais melhores que os do Alto Piranhas e de Espinharas, com: 77\%, em 2015, aumentou para 86\%, em 2017, e 99\% em 2019, com média igual a 88\%. Em Espinharas, a média foi de 72\%, a mais baixa comparada com as outras microrregiões, o seu indicador de desempenho financeiro foi de: 61\%, em 2015, aumentou para 71\%, em 2017, e chegou a 84\%, em 2019 (Gráfico $8)$.

Gráfico 8: Indicador de desempenho financeiro (IN012).

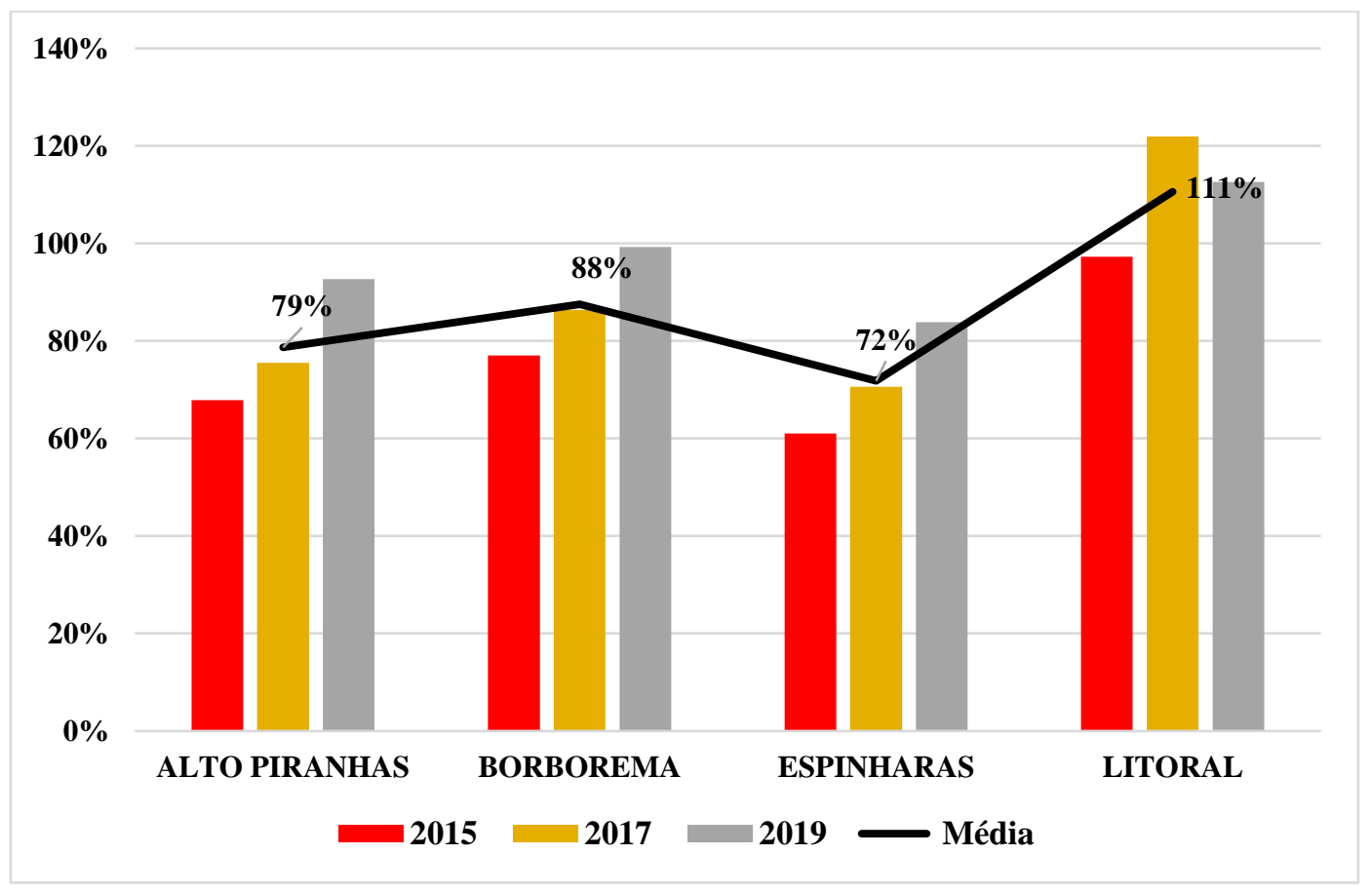

Fonte: Autores, com base em dados do SNIS (2021).

A Microrregião do Litoral, além de apresentar cenários climáticos e hídricos favoráveis, possui o melhor desempenho financeiro, sendo a única microrregião com sustentabilidade econômico-financeira. Embora em 2015, não tenha atingido 100\% no indicador de desempenho financeiro, chegou próximo, com 97\%. Em 2017, esse indicador foi de 122\%, em 2019, caiu para $113 \%$, e a média do indicador de desempenho financeiro foi de 111\%. Alto Piranhas, Borborema e Espinharas não atingiram $100 \%$ em nenhum dos anos analisados e a média também ficou abaixo desse percentual, embora tenham apresentado aumento do indicador de desempenho financeiro ao longo dos anos. 
Quando os responsáveis técnicos pela definição das Microrregiões de Água e Esgoto da Paraíba foram perguntados sobre como fica o subsídio cruzado, responderam, como consta no Anexo V da Lei Complementar n. 168 (2021): "Cada microrregião deverá ser autossuficiente em termos de viabilidade financeira, portanto, não haverá necessidade de subsídio cruzado entre microrregiões", (Governo do Estado da Paraíba, 2021). No entanto, não é o que mostra o indicador de desempenho financeiro (Figura 9), o indicador de suficiência de caixa e outros dados econômicos que serão analisados. O mapa mostra quais são os municípios paraibanos que possuem indicador de desempenho financeiro acima e abaixo de $100 \%$.

Figura 9: Mapa de indicador de desempenho financeiro dos municípios paraibanos.

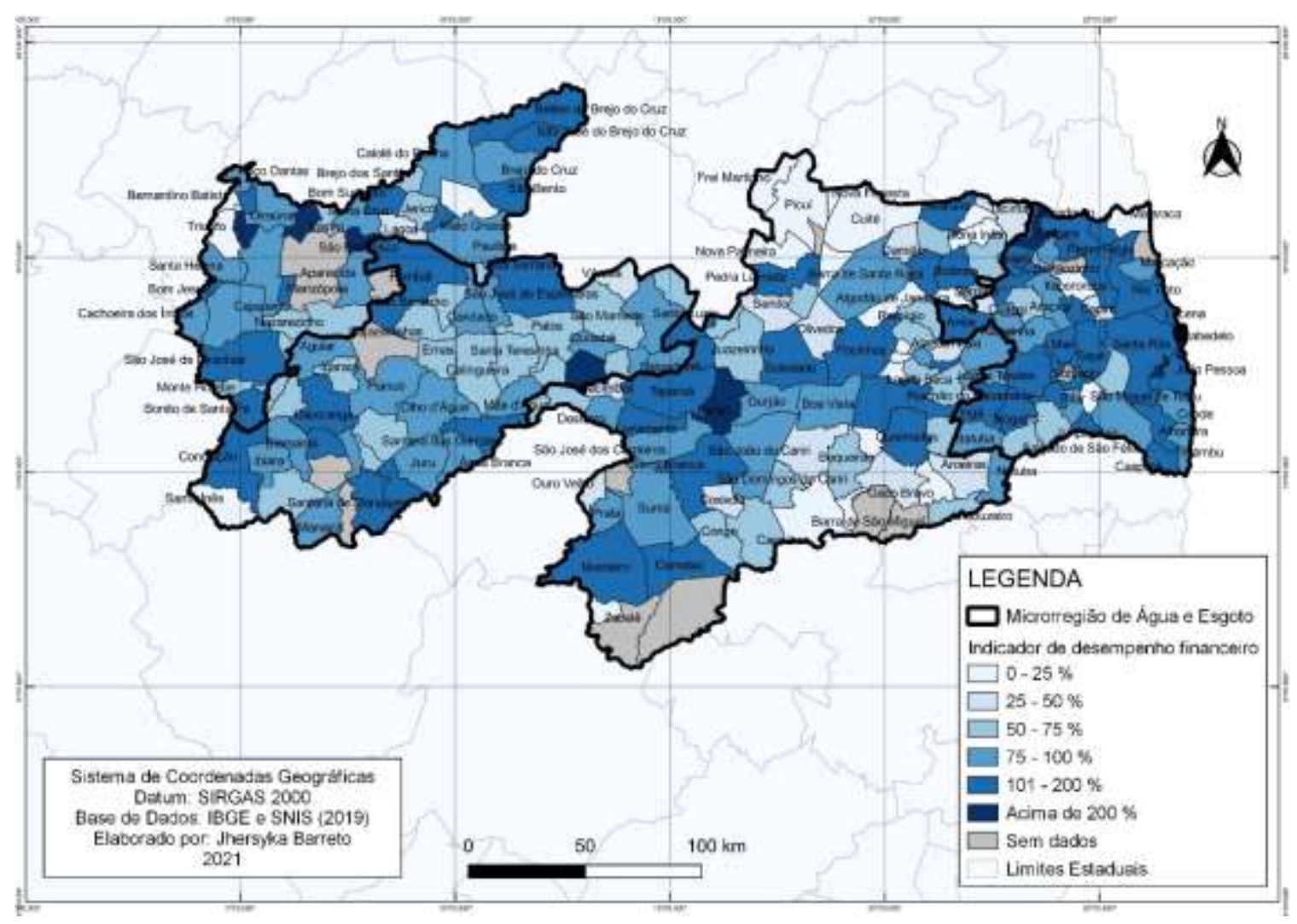

Fonte: Autores (2021).

A Microrregião do Litoral é a que apresenta mais municípios com o indicador de desempenho financeiro acima de $100 \%$, são 28 , o que corresponde a $50,9 \%$ dos municípios dessa microrregião, outros $23,6 \%$ estão na faixa de 75 a $100 \%$, apenas 5,5\% dos municípios estão na faixa de 0 a $25 \%$ de desempenho financeiro. Alto Piranhas apresenta $34,2 \%$ dos municípios acima de $100 \%$ em relação a esse indicador, outros $26,3 \%$ estão na faixa entre 75 e $100 \%$ e, aproximadamente, $8 \%$ possuem indicador de desempenho financeiro entre 0 e $25 \%$. Borborema tem apenas 21,4\% dos municípios com resultado acima de $100 \%$ para esse indicador, outros 15,5\% estão na faixa entre 75 e $100 \%$ e, aproximadamente, $24 \%$ não apresentam desempenho financeiro, pois apresentou resultado igual a zero, com exceção de um município que teve o resultado de 6,8\%. Espinharas apresentou 19,6\% dos municípios com indicador de desempenho financeiro acima de $100 \%$, outros $32,6 \%$ com resultados entre 75 e $100 \%$, e apenas 2,2\% com resultados do indicador entre 0 e $25 \%$. Ou seja, o Litoral e Alto Piranhas apresentaram resultados mais favoráveis quanto ao desempenho financeiro dos seus municípios.

As médias da receita operacional direta total das Microrregiões, demonstram que estão concentradas, principalmente, na Microrregião do Litoral, que corresponde a cerca de $61 \%$ do total das receitas operacionais diretas. As demais Microrregiões somam 39\% dessas receitas, distribuídas entre: Alto Piranhas, com cerca de 6\%; Borborema, com 25\%; e Espinharas, com 8\% 
(Gráfico 9). A viabilidade técnica e sustentabilidade econômico-financeira das microrregiões deveria ter sido exaustivamente discutida em audiência pública e na sessão ordinária da ALPB para que fosse garantida a autossuficiência de todas as microrregiões. Caso a Microrregião do Litoral seja privatizada, quais serão as consequências para essas três Microrregiões, que juntas correspondem a $75 \%$ dos municípios paraibanos e menos de $40 \%$ das receitas operacionais diretas?

Gráfico 9: Receita operacional direta total (FN001).

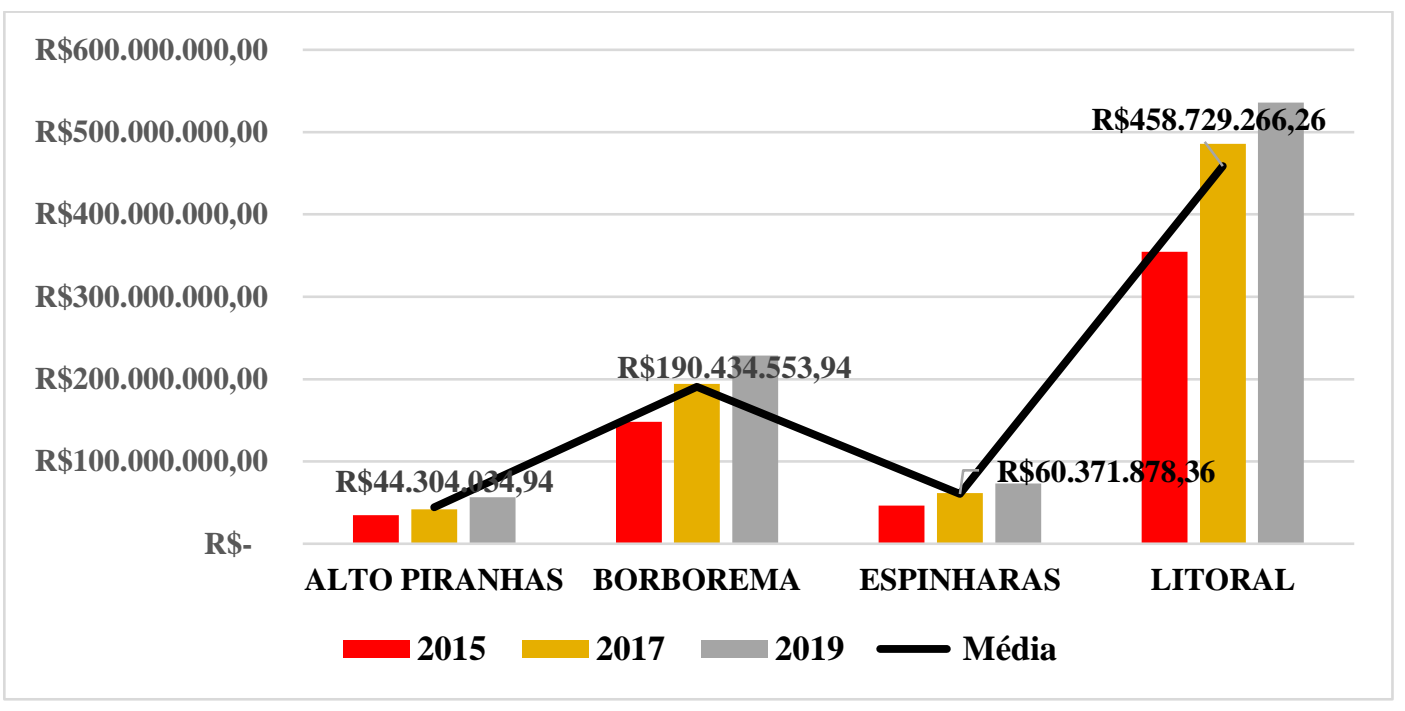

Fonte: Autores, com base em dados do SNIS (2021).

Em relação a composição das receitas operacionais diretas das Microrregiões, a que apresenta maior contribuição é a receita de água (FN002), seguida da receita de esgoto (FN003), as receitas de água exportada (FN007) e esgoto bruto importado (FN038) são mínimas. Para possibilitar uma compreensão mais detalhada das receitas operacionais diretas, foram adotadas as médias dos indicadores em relação aos dados dos três anos em estudo (2015, 2017 e 2019) para identificar a participação percentual de cada receita na média FN001 de cada Microrregião (Tabela 3).

Tabela 3: Médias das receitas operacionais diretas.

\begin{tabular}{l|l|l|l|l} 
MICRORREGIÃO & FN002 $(\boldsymbol{\%})$ & FN003 $(\boldsymbol{\%})$ & FN007 $(\boldsymbol{\%})$ & FN038 $(\boldsymbol{\%})$ \\
\hline ALTO PIRANHAS & 88,6 & 7,0 & 4,4 & 0 \\
\hline BORBOREMA & 71,4 & 28,6 & 0 & 0 \\
\hline ESPINHARAS & 95,4 & 4,6 & 0 & 0 \\
\hline LITORAL & 68,0 & 32,0 & 0 & 0
\end{tabular}

FN002: Receita operacional direta de água; FN003: Receita operacional direta de esgoto; FN007: Receita operacional direta de água exportada (bruta ou tratada); FN038: Receita operacional direta - esgoto bruto importado. Fonte: Autores, com base em dados do SNIS (2021).

Em Alto Piranhas, a receita operacional direta de água correspondeu a 88,6\% e a de esgoto a 7\%, em razão do baixo atendimento dos serviços de esgotamento sanitário nos municípios da microrregião, além disso, é a única que apresentou receita de água exportada (bruta ou tratada), que foi de 4,4\%, devido a receita de R \$5,8 milhões, em 2019. Na Borborema, a média de FN001 é composta por 71,4\% de receita operacional direta de água e 28,5\% de receita direta de esgoto. Espinharas tem a média de FN001 composta por 95,4\% das receitas operacionais diretas de água e 4,6\% das de esgoto. A Microrregião do Litoral, é a 
que apresenta a maior receita operacional direta de esgoto, sendo 32\% da média de FN001 e os $68 \%$ são provenientes de receitas diretas de água, com FN007 e FN038 iguais a zero, como em Borborema e Espinharas.

A média das despesas totais com os serviços (FN017), nos anos analisados, é superior à média da receita operacional direta total (IN001) em Alto Piranhas, Borborema e Espinharas, por essa razão o IN012 dessas microrregiões é inferior a 100\%. Apenas a Microrregião do Litoral apresenta a média da receita operacional direta total superior à média das despesas com os serviços, por ser a única superavitária (Tabela 4).

Tabela 4: Despesas totais com os serviços (DTS) (FN017).

\begin{tabular}{l|l|l|l|l} 
MICRORREGIÕES & $\mathbf{2 0 1 5}$ & $\mathbf{2 0 1 7}$ & $\mathbf{2 0 1 9}$ & Média \\
\hline ALTO PIRANHAS & $\mathrm{R} \$ 51.073 .989,72$ & $\mathrm{R} \$ 55.173 .790,15$ & $\mathrm{R} \$ 61.029 .822,93$ & $\mathrm{R} \$ 55.759 .200,93$ \\
\hline BORBOREMA & $\mathrm{R} \$ 192.507 .710,24$ & $\mathrm{R} \$ 225.094 .877,19$ & $\mathrm{R} \$ 230.357 .992,98$ & $\mathrm{R} \$ 215.986 .860,14$ \\
\hline ESPINHARAS & $\mathrm{R} \$ 75.684 .158,02$ & $\mathrm{R} \$ 87.460 .246,41$ & $\mathrm{R} \$ 87.174 .753,42$ & $\mathrm{R} \$ 83.439 .719,28$ \\
\hline LITORAL & $\mathrm{R} \$ 364.346 .870,38$ & $\mathrm{R} \$ 398.359 .274,26$ & $\mathrm{R} \$ 475.745 .310,55$ & $\mathrm{R} \$ 412.817 .151,73$
\end{tabular}

Fonte: Autores, com base em dados do SNIS (2021).

O outro indicador adotado foi o de suficiência de caixa (IN101), que é composto pela arrecadação total (FN006) dividida pela soma das despesas - despesas de exportação (FN015), despesas com juros e encargos do serviço da dívida (FN016), despesas fiscais ou tributárias não computadas na DEX (FN022) e despesas com amortizações do serviço da dívida (FN034). Os resultados reforçam o que o indicador de desempenho financeiro (IN012) apontou sobre a sustentabilidade econômico-financeira das microrregiões paraibanas, que apenas a Microrregião do Litoral é sustentável.

A Microrregião de Alto Piranhas apresentou uma média de 85\%, em relação ao índice de suficiência de caixa, Borborema apresentou 91\% e Espinharas 87\%, ou seja, essas microrregiões possuem insuficiência de caixa, pois as despesas totais para manter os serviços de água e esgoto são superiores à arrecadação total dos seus municípios. Por outro lado, a Microrregião do Litoral apresentou índice médio de suficiência de caixa superavitário, com 112\%, o que demonstra que os valores totais arrecadados são superiores aos valores das despesas totais para manter os serviços de água e esgoto nos municípios dessa microrregião (Gráfico 10), com muitos municípios com o IN101 favorável. 
Gráfico 10: Índice de suficiência de caixa (IN101).

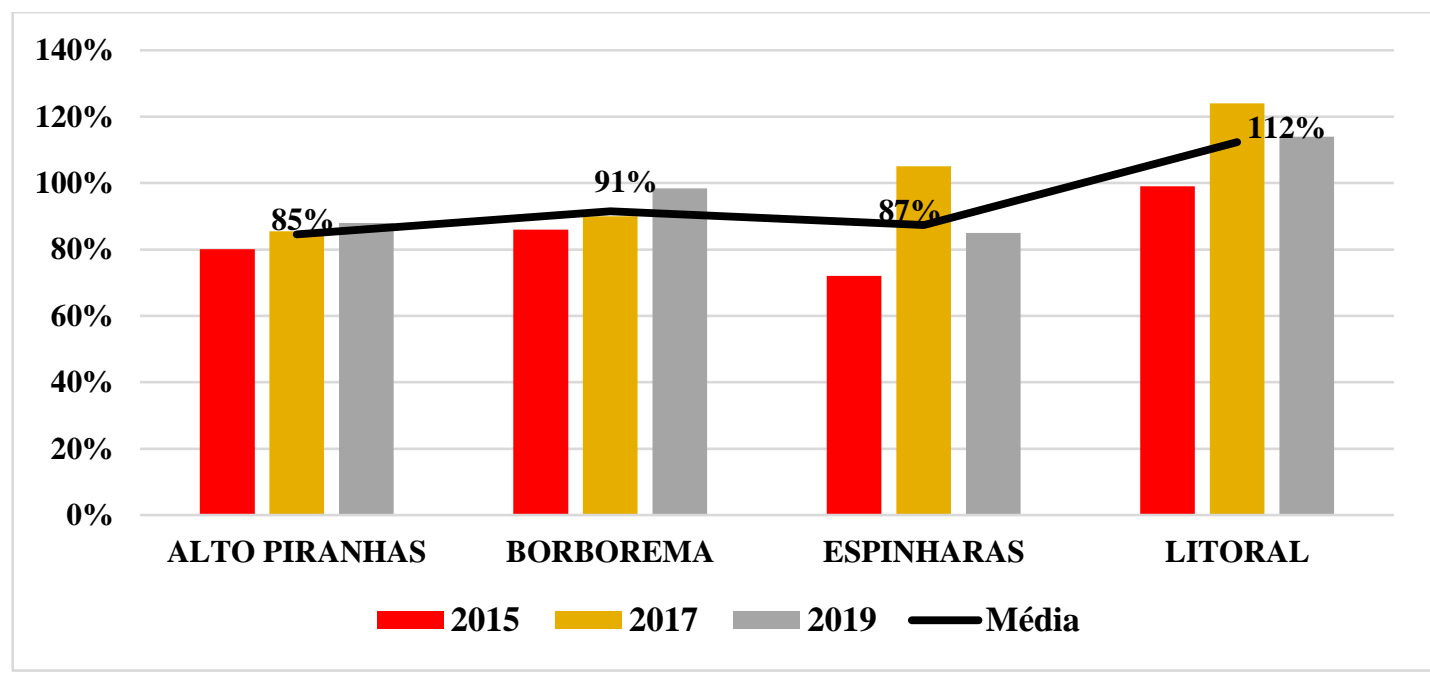

Fonte: Autores, com base em dados do SNIS (2021).

De acordo com o SNIS (2019), "a arrecadação total (FN006) é o valor anual efetivamente arrecadado de todas as receitas operacionais, diretamente nos caixas do prestador de serviços ou por meio de terceiros autorizados (bancos e outros)". A Tabela 5 mostra os dados de arrecadação total por ano e a média por microrregiões, que foram utilizados para o cálculo do índice de suficiência de caixa (IN101).

Tabela 5: Arrecadação total (FN006).

\begin{tabular}{l|l|l|l|l} 
FN006 & $\mathbf{2 0 1 5}$ & $\mathbf{2 0 1 7}$ & \multicolumn{1}{c}{$\mathbf{2 0 1 9}$} & Média \\
\hline ALTO PIRANHAS & $\mathrm{R} \$ 35.593 .372,81$ & $\mathrm{R} \$ 44.171 .616,63$ & $\mathrm{R} \$ 52.812 .493,04$ & $\mathrm{R} \$ 44.192 .494,16$ \\
\hline BORBOREMA & $\mathrm{R} \$ 145.237 .954,95$ & $\mathrm{R} \$ 190.980 .668,75$ & $\mathrm{R} \$ 225.014 .615,16$ & $\mathrm{R} \$ 187.077 .746,29$ \\
\hline ESPINHARAS & $\mathrm{R} \$ 47.334 .866,76$ & $\mathrm{R} \$ 86.835 .655,66$ & $\mathrm{R} \$ 75.348 .845,02$ & $\mathrm{R} \$ 69.839 .789,15$ \\
\hline LITORAL & $\mathrm{R} \$ 323.806 .104,00$ & $\mathrm{R} \$ 468.870 .470,11$ & $\mathrm{R} \$ 536.014 .010,37$ & $\mathrm{R} \$ 442.896 .861,49$
\end{tabular}

Fonte: Autores, com base em dados do SNIS (2021).

A Tabela 6 apresenta o resultado da soma das despesas por ano e a média por microrregiões, esses foram os dados utilizados para o cálculo do índice de suficiência de caixa (IN101). Os indicadores e informações analisados demonstram que, a divisão em Microrregiões de Água e Esgoto da Paraíba, beneficia o Litoral em detrimento das demais, que não possuem sustentabilidade econômico-financeira e nem cenários climáticos favoráveis para a garantia da segurança hídrica nos períodos mais críticos. 
Tabela 6: Resultado da soma das despesas que compõem o IN101.

\begin{tabular}{l|l|l|l|l} 
MICRORREGIÕES & $\mathbf{2 0 1 5}$ & $\mathbf{2 0 1 7}$ & $\mathbf{2 0 1 9}$ & Média \\
\hline ALTO PIRANHAS & $\mathrm{R} \$ 44.433 .397,33$ & $\mathrm{R} \$ 51.635 .442,15$ & $\mathrm{R} \$ 59.791 .435,57$ & $\mathrm{R} \$ 51.953 .425,02$ \\
\hline BORBOREMA & $\mathrm{R} \$ 168.832 .130,46$ & $\mathrm{R} \$ 211.890 .070,32$ & $\mathrm{R} \$ 230.251 .522,92$ & $\mathrm{R} \$ 203.657 .907,90$ \\
\hline ESPINHARAS & $\mathrm{R} \$ 65.643 .017,55$ & $\mathrm{R} \$ 82.646 .373,02$ & $\mathrm{R} \$ 88.695 .273,23$ & $\mathrm{R} \$ 78.994 .887,93$ \\
\hline LITORAL & $\mathrm{R} \$ 326.541 .369,79$ & $\mathrm{R} \$ 378.064 .470,21$ & $\mathrm{R} \$ 469.307 .866,83$ & $\mathrm{R} \$ 391.304 .568,94$
\end{tabular}

FN015: Despesas de Exploração (DEX); FN016: Despesas com juros e encargos do serviço da dívida; FN022: Despesas fiscais ou tributárias não computadas na DEX; FN034: Despesas com amortizações do serviço da dívida. Fonte: Autores, com base em dados do SNIS (2019).

Em caso de privatização total ou parcial dos serviços de água e esgoto da Microrregião do Litoral - considerada parcial quando há a concessão do serviço de distribuição de água para empresas privadas e a prestação dos serviços de captação e tratamento da água bruta continua sendo realizada pela empresa pública estadual (CAGEPA) -, haverá a transferência da maior parcela das receitas operacionais diretas da Paraíba para o setor privado. Uma queda de mais de $60 \%$ das receitas operacionais diretas pode comprometer a sustentabilidade econômico-financeira da CAGEPA e a manutenção dos serviços públicos de água e esgotamento sanitário, que atualmente são prestados pela empresa em mais de 200 municípios da Paraíba. Além disso, o que garantia a manutenção dos serviços de abastecimento de água nos cenários mais críticos e nas localidades deficitárias é a possibilidade de aplicar o subsídio cruzado entre os municípios paraibanos, o que foi inviabilizado pelas alterações da Lei Federal $\mathrm{n}^{\circ}$ 14.026/2020 e pela Lei Complementar 168/2021, na Paraíba.

O Estudo Técnico (2021) não apresentou os dados das receitas operacionais diretas por microrregião e nem os indicadores financeiros que possibilitassem a compreensão da (in)sustentabilidade econômico-financeira das Microrregiões de Água e Esgoto da Paraíba. A única tabela com dados de receitas é a que apresenta a razão entre as receitas indiretas, que são os recursos provenientes de terceiros, como Estado e União, e as receitas operacionais diretas, que são recursos próprios provenientes das receitas dos serviços operacionais prestados nos municípios (Figura 10). Ou seja, o Estudo Técnico (2021) apresentou uma tabela insignificante e deixou de fora dados relevantes sobre as receitas operacionais diretas e os indicadores financeiros das Microrregiões.

Figura 10: Razão entre receitas operacionais diretas e indiretas por microrregião.

Tabela 6.2 - Microrregiōes de saneamento básico da Paraíba: razōes entre as receitas
operacionais indiretas e as receitas diretas (de 2015 a 2019/20)
\begin{tabular}{|c|c|c|c|c|c|c|}
\hline Microrregiōes & 2015 & 2016 & 2017 & 2018 & 2019 & Médias \\
\hline Alto Piranhas & 16,07 & 28,00 & 9,62 & 6,49 & 6,31 & 13,30 \\
\hline Borborema & 14,79 & 19,68 & 6,77 & 5,05 & 6,26 & 10,51 \\
\hline Espinharas & 17,07 & 32,43 & 7,76 & 6,22 & 7,15 & 14,13 \\
\hline Litoral & 10,07 & 17,67 & 6,42 & 5,23 & 5,03 & 8,88 \\
\hline
\end{tabular}
Fontes: ANA, CAGEPA, IBGE e SNIS. Elaboraçäo própria.

Fonte: Estudo Técnico (Fundace, 2021).

Outra fragilidade apresentada pelo referido estudo é que, embora nas considerações finais conste que "para a proposta de regionalização foram levadas em consideração diversos aspectos: municípios limítrofes, sistemas integrados, bacias hidrográficas, presença de adutoras, obras de integração, regionalização da saúde, entre diversos outros fatores" (Estudo Técnico, 2021, p. 65), não há nada sobre as Bacias Hidrográficas da Paraíba, sobre o PISF e demais componentes da infraestrutura hídrica dos municípios paraibanos, como a situação das adutoras e área de influência. Mesmo diante da relevância dessas informações 
para o desenvolvimento de um Planejamento Regional de Saneamento Básico, que esteja integrado com as demais unidades de planejamento e gestão dos recursos hídricos. Não iremos abordar todas as fragilidades desse estudo, mas é necessário deixar claro que ele não apresenta os principais dados do estudo de viabilidade técnica e de sustentabilidade econômico-financeira e ambiental das Microrregiões de Água e Esgoto da Paraíba.

Um fato que merece destaque em relação ao processo de regionalização do saneamento na Paraíba é que a Minuta de Lei Complementar (PLC, 2021b), que deu entrada no protocolo da ALPB e foi aprovada, não foi a mesma que foi disponibilizada para a comunidade e discutida em audiência pública (PLC, 2021a), no dia 18 de maio de 2021 (SEIRHMA PB, 2021; TV ASSEMBLEIA PB, 2021b). As principais diferenças observadas referem-se a inclusão de atribuições do Colegiado Microrregional (art. 7, dos incisos VII ao XI):

(...)VII - autorizar Município a prestar isoladamente os serviços públicos de abastecimento de água ou de esgotamento sanitário, ou atividades deles integrantes, inclusive mediante criação de órgão ou entidade ou a celebração de contrato de concessão ou de ajuste vinculado à gestão associada de serviços públicos;

VIII - - manifestar-se em nome dos titulares sobre as matérias regulatórias e contratuais, inclusive as previstas no Decreto federal $\mathrm{n}^{\circ} 10.710$, de 31 de maio de 2021, bem como aditar contratos para preservar o ato jurídico perfeito mediante reequilíbrio econômico-financeiro, especialmente quando o reequilíbrio se realizar mediante dilação ou diminuição de prazo contratual;

IX - autorizar a alienação de participações societárias, ocasione ou não a mudança de controle, de empresas que integrem a Administração Indireta da Microrregião;

X - autorizar Município integrante da Microrregião a participar, como convenente, de estruturas de prestação regionalizada de serviços públicos de abastecimento de água e de esgotamento sanitário de Estado limítrofe;

XI - autorizar a prestação direta dos serviços públicos de abastecimento de água e esgotamento sanitário pela Companhia de Água e Esgotos da Paraíba - CAGEPA, em razão desta integrar a administração indireta de um dos entes da entidade microrregional;(...). (Projeto de Lei Complementar, 2021b).

E inclusão de novos artigos nas Disposições Finais e Transitórias:

Art. 13. Fica o Chefe do Poder Executivo autorizado a celebrar convênio de cooperação entre entes federados para que os Municípios paraibanos possam se conveniar com microrregiões instituídas por Estados limítrofes.

Art. 14. Fica o Poder Executivo autorizado a:

I - criar subsidiárias da Cagepa - Companhia de Águas e Esgotos da Paraíba, Sociedades de Propósito Específico - SPE ou outras sociedades empresárias, com atuação em uma ou mais das microrregiões instituídas por esta Lei Complementar;

II - modificar a natureza das ações e de outras participações societárias que possua, diretamente ou por meio de entidades da Administração Indireta, na Cagepa - Companhia de Águas e Esgotos da Paraíba e nas subsidiárias mencionadas no inciso I deste artigo;

III - a alienar, de forma gratuita ou onerosa, as ações e participações societárias mencionadas no inciso II deste artigo, inclusive o controle da Cagepa ou de qualquer das suas subsidiárias, exclusivamente para uma ou mais das microrregiões instituídas por esta Lei Complementar.

Parágrafo único: Excluem-se das autorizações previstas nos incisos I a III deste artigo, a abertura de capital que somente poderá ser autorizada mediante lei específica. (Projeto de Lei Complementar, 2021b).

A inclusão dessas atribuições do Colegiado Microrregional e dos novos artigos estão relacionadas com o Decreto Federal nº 10.710 (2021) e a possibilidade de alienação da CAGEPA. No entanto, não houve nova consulta ou audiência pública para discutir as alterações. O PLC foi para a votação na ALPB, sem que os deputados estaduais tivessem um prazo para ler e analisar o estudo técnico e a Minuta da Lei, pois receberam esses documentos em menos de 24h do início da sessão ordinária, onde foi aprovado o Projeto de Lei (TV ASSEMBLEIA PB, 2021b).

\section{Considerações Finais}

As Microrregiões de Água e Esgoto da Paraíba definirão os rumos futuros dos serviços de abastecimento de água e 
esgotamento sanitário nos municípios paraibanos. Ainda não se sabe ao certo quais serão as consequências negativas e positivas para os municípios e para os paraibanos, nem para a CAGEPA e os prestadores locais. Mas, impor uma regionalização, sem que fossem apresentadas outras alternativas e sem que os estudos de viabilidade técnica, econômico-financeira e ambiental fossem exaustivamente discutidos pelos atores envolvidos, centraliza as responsabilidades em quem propôs e em quem aprovou essas microrregiões, instituídas pela Lei Complementar 168 (2021). Este artigo tentou compensar a ausência de dados e discussões do processo de regionalização do saneamento na Paraíba, com a abordagem, de forma didática e ilustrativa, de informações e indicadores necessários à compreensão das Microrregiões da Paraíba, sem a tentativa de homogeneizá-las, ao contrário, evidenciando suas diferenças.

De acordo com a Lei Federal n 14.026/2020, a regionalização do saneamento visa a geração de ganhos de escala, a garantia da universalização, da viabilidade técnica e econômico-financeira dos serviços. No entanto, a regionalização do saneamento da Paraíba pode comprometer a universalização dos serviços em Alto Piranhas, Borborema e Espinharas, que são microrregiões que não apresentam viabilidade técnica e sustentabilidade econômico-financeira. Condicionar 75\% dos municípios paraibanos a pertencerem a essas microrregiões, que dependerão de receitas indiretas para manutenção dos serviços existentes e ampliação com vistas à universalização desses serviços, é assumir os riscos de acentuar as desigualdades de acesso e distribuição dos serviços de água e esgoto entre os municípios e microrregiões.

Sem o subsídio cruzado, apenas a microrregião do Litoral, que é superavitária, terá condições de arcar com os seus próprios custos e investir na ampliação dos serviços com recursos de receitas operacionais diretas, além disso, terá mais facilidade de acessar receitas indiretas por poder comprovar a sua sustentabilidade econômico-financeira. Diferente da unidade regional de saneamento, dos blocos de referência e da gestão associada, que necessitam da adesão do titular dos serviços públicos de água e esgoto, as microrregiões não precisam da adesão, pois, assim como as regiões metropolitanas e aglomerações urbanas, são instituídas por lei complementar correspondente (Lei Federal nº 13.089, 2015; Decreto Federal n 10.588, 2020).

Diante disso, faz-se necessário que os gestores dos municípios paraibanos, sobretudo dos municípios de até 50 mil habitantes, que correspondem a 213 municípios do Estado, estejam atentos e unam esforços para desenvolver os seus diagnósticos, suas metas prioritárias e, se possível, o Plano Municipal de Saneamento Básico (PMSB). Pois é importante que cada município tenha estabelecido suas metas prioritárias para o setor, de forma que os gestores possam solicitar que essas metas sejam consideradas e incluídas ao Plano Regional de Saneamento Básico (PRSB), quando este estiver em processo de elaboração. Além disso, é indispensável que os gestores e a população paraibana cobrem ao Governo Estadual e aos demais envolvidos que haja o máximo de transparência, diálogo e participação na gestão dos serviços públicos de saneamento básico e na elaboração do PRSB, para que não continuem a reproduzir a metodologia adotada durante todo o processo de regionalização, o qual muitos paraibanos, inclusive gestores, desconhecem pela falta de transparência e divulgação desse processo. Cabe à população pressionar os gestores municipais, estaduais e federais para que garantam o acesso à informação, com a publicidade e a transparência das informações de interesse público, para o pleno desenvolvimento do controle social e da participação na gestão pública.

Atualmente, o Brasil cede às pressões de organizações internacionais e nacionais, como o Banco Nacional de Desenvolvimento Econômico e Social (BNDES), para aderir à privatização dos serviços de saneamento e de empresas estatais. A tendência é que, com o "Novo Marco Regulatório do Saneamento", aumente as concessões privadas dos serviços de água e esgotamento sanitário. A CAGEPA e os serviços de água e esgoto da Paraíba são alvos de interesse do setor de desestatização do BNDES, que tem atuado, inicialmente, por meio da privatização dos serviços, como ocorreu com a CEDAE e a CASAL (BNDES, 2017; BNDES, 2021a; BNDES, 2021b). A mercantilização do setor de saneamento, que perde cada vez mais espaço nos outros países do mundo, encontra no Brasil um contexto favorável para expandir os seus negócios de forma regionalizada.

A CAGEPA é uma empresa pública superavitária, sua sustentabilidade econômico-financeira é evidenciada todo ano 
por meio do lucro líquido obtido. Em 2017, depois de anos de estiagem e em período de racionamento do abastecimento de água, esse lucro foi R \$67,7 milhões (Companhia de Água e Esgoto da Paraíba - CAGEPA, 2018). Em 2018, teve um lucro recorde de $\mathrm{R} \$ 109,8$ milhões (CAGEPA, 2019). Em 2019, o lucro se manteve alto, mesmo com uma queda em relação ao ano anterior, totalizando R $\$ 99,7$ milhões (CAGEPA, 2020). E, em 2020, mesmo com o aumento das despesas devido à pandemia do Coronavírus e despesas jurídicas, a empresa obteve lucro líquido de R \$7,9 milhões (CAGEPA, 2021).

Ou seja, mesmo diante de diferentes cenários climáticos, econômico e até pandêmico, que afetaram a Paraíba nos últimos anos, a CAGEPA manteve sua sustentabilidade econômico-financeira e a manutenção dos serviços prestados. Além disso, a abrangência regional da CAGEPA permite a prestação dos serviços por meio de compartilhamento tanto de infraestruturas operacionais, como de recursos financeiros, que possibilitam a aplicação do subsídio cruzado, que é o que garante, até o presente momento, a manutenção dos serviços em municípios deficitários. É necessário compreender a importância dos serviços públicos de abastecimento de água e esgotamento sanitário, enquanto direito humano essencial, e a contribuição da CAGEPA para a garantia do acesso aos serviços de abastecimento de água nos períodos mais críticos e, principalmente, para os que não podem pagar.

No momento em que o Brasil caminha para a privatização regionalizada dos serviços de saneamento, Kishimoto, Steinfort e Petitjean (2020) apontam para um futuro público em relação a prestação desses serviços, com inúmeros casos de remunicipalizações da prestação de serviços de abastecimento de água, esgotamento sanitário, resíduos sólidos e drenagem urbana, entre outros serviços de interesse público. Nos países mais ricos e desenvolvidos do mundo, como França, Estados Unidos, Espanha e Alemanha, assim como em países mais pobres e em desenvolvimento, como Bolívia, Peru, Argentina, Uruguai e México, a privatização da água e dos serviços de saneamento relacionados a esse recurso foi um fracasso. E resultou no fim de muitas concessões privadas, com casos na escala municipal, regional e nacional, que geravam lucros exorbitantes para os acionistas das multinacionais/transnacionais e bancos que financiaram a privatização (Kishimoto, S., Lobina, E. \& Petitjean, O., 2015). Enquanto o lucro era acumulado por alguns, os prejuízos econômicos, ambientais e sociais decorrentes do fracasso das privatizações eram socialmente distribuídos.

Qual a razão da urgência de alterar legislações do setor de saneamento e aprovar a regionalização desses serviços nos Estados em um período de pandemia? Uma pandemia que vitimou tantos brasileiros e todos, sem exceção, tentam sobreviver ao caos que tem sido o enfrentamento dessa pandemia no Brasil. Esse seria o momento ideal para os representantes do povo, reconhecerem a importância de fortalecer as instituições públicas e investir na ampliação e melhoria dos serviços públicos, como os prestados pelo Sistema Único de Saúde (SUS), que garante o acesso universal aos serviços de saúde; pelas empresas estatais de água e esgoto, que garantem o acesso a esses serviços essenciais para a manutenção da salubridade ambiental, higiene pessoal e saúde da população; pelas Instituições Públicas de Ensino, Pesquisa e Extensão, que contribuem para o desenvolvimento das ciências e tecnologias, como o desenvolvimento de vacinas, que ajudarão o mundo a sair dessa pandemia, entre outras instituições e serviços públicos relevantes para o desenvolvimento do Brasil. Esse não deveria ser o momento de violar direitos, enfraquecer as instituições públicas e privatizar serviços públicos e bens essenciais, como a água. Nesse sentido, há de se concordar com Castro, Heller e Morais (2015), o surgimento do direito humano à água tem sido tão lento quanto controverso.

\section{Agradecimentos}

Agradecemos ao Programa de Pós-graduação em Engenharia e Gestão de Recursos Naturais (PPGEGRN), da Universidade Federal de Campina Grande (UFCG), e a todas as universidades públicas, gratuitas e de qualidade, que seguem contribuindo para o desenvolvimento tecnológico e científico do Brasil, mesmo diante das tentativas de desmonte e precarização dos serviços públicos. Agradecemos também aos órgãos de fomento à pesquisa, que são de extrema importância para a produção 
científica brasileira.

\section{Referências}

AESA (2021b). Download dos dados de monitoramento do volume dos açudes da Paraíba. http://www.aesa.pb.gov.br/aesa-website/monitoramento/

AESA (2021c). Água da maior obra de infraestrutura hídrica da Paraíba chega ao canal Acauã-Araçagi. http://www.aesa.pb.gov.br/aesawebsite/2021/01/27/chega-agua-na-maior-obra-de-infraestrutura-hidrica-da-paraiba-canal-acaua-aracagi/

Agência de Gestão das Águas da Paraíba [AESA] (2021a). Semana Estadual de Mobilização em Defesa da Água (AESA), dia 23 de março de 2021.http://www.aesa.pb.gov.br/aesa-website/2021/03/26/video-obras-do-projeto-de-integracao-do-rio-sao-francisco-que-beneficiarao-a-paraiba-apresentacaona-semana-da-agua/

BNDES (2017). Pregão eletrônico 32/17. https://www.bndes.gov.br/wps/portal/site/home/transparencia/licitacoes-contratos/licitacoes/pregoeseletronicos/2017/pregao-eletronico-2017-32

BNDES (2021a). BNDES fará estudos para ampliar saneamento na Paraíba. https://www.bndes.gov.br/wps/portal/site/home/imp rensa/noticias/conteudo/bndes-fara-estudos-para-ampliar-\%20saneamento-na-paraiba

BNDES (2021b). Processos em andamento - Desestatização. https://www.bndes.gov.br/wps/portal/site/home/transparencia/desestatizacao/processos-emandamento

CAGEPA (2017). Relatório da Administração e de Sustentabilidade e Balanço. http://www.cagepa.pb.gov.br/wp-content/uploads/2015/02/Relat\%C3\%B3rioda-Administra\%C3\%A7\%C3\%A3o-e-de-Sustentabilidade-e-Balan\%C3\%A7o-2017.pdf

CAGEPA (2018). Relatório da Administração $e$ de Sustentabilidade $e \quad$ Balanço. http://www.cagepa.pb.gov.br/wpcontent/uploads/2019/04/Relat\%C3\%B3rio_da_Administra\%C3\%A7\%C3\%A3o_e_de_Sustentabilidade_e_Balan\%C3\%A7o_2018.pdf

CAGEPA (2019). Relatório da Administração e de Sustentabilidade e Balanço. http://www.cagepa.pb.gov.br/wp-content/uploads/2020/05/Relat\%C3\%B3rioda-Administra\%C3\%A7\%C3\%A3o-e-de-Sustentabilidade-e-Balan\%C3\%A7o-2019.pdf

CAGEPA (2020). Relatório da Administração e de Sustentabilidade e Balanço. http://www.cagepa.pb.gov.br/wp-content/uploads/2021/05/Relat\%C3\%B3rioda-Administra\%C3\%A7\%C3\%A3o-e-de-Sustentabilidade-e-Balan\%C3\%A7o-2020.pdf

Castro, J. E. (2016a). Água e democracia na América Latina [Livro Eletrônico]. /Jose Esteban Castro. - Campina Grande: EDUEPB, 2016. 450p. http://www.uepb.edu.br/ebooks

Castro, J. E. (2016b). A dimensão teórica da participação e do controle social (29 - 49 p.). In: Héller, L., Aguiar, M. \& Rezende, S. C. (Orgs.). Participação e controle social em saneamento básico: conceitos, potencialidades e limites.

Castro, J. E., Cunha, L. H., Fernandes, M. e Sousa, C. M. (2017). Tensão entre Justiça Ambiental e Social na América Latina. Campina Grande: EDUEPB. pp. 417.

Castro, J. E., Heller, L., Morais, M. P. (2015). O direito à água como política pública na América Latina: uma exploração teórica e empírica. Brasília: Ipea. 322 p. ISBN: 978-85-7811-238-7

Chang, H. (2004). Chutando a escada: a estratégia do desenvolvimento em perspectiva histórica. UNESP (tradução). 135 p.

Constituição da República Federativa do Brasil de 1988. (1998). www.planalto.gov.br/ccivil_03/constituicao/constituicao.htm

DECRETO No 10.588 (2020), de 24 de dezembro de 2020. Dispõe sobre o apoio técnico e financeiro de que trata o art. 13 da Lei $\mathrm{n}^{\circ} 14.026$, de 15 de julho de 2020 , sobre a alocação de recursos públicos federais e os financiamentos com recursos da União ou geridos ou operados por órgãos ou entidades da União de que trata o art. 50 da Lei $n^{\circ}$ 11.445, de 5 de janeiro de 2007. https://www.in.gov.br/en/web/dou/-/decreto-n-10.588-de-24-de-dezembro-de-2020-296387871

Decreto Federal no 10.710 (2021), de 31 de maio de 2021. Regulamenta o art. 10-B da Lei $\mathrm{n}^{\mathrm{o}} 11.445$, de 5 de janeiro de 2007 , para estabelecer a metodologia para comprovação da capacidade econômico-financeira dos prestadores de serviços públicos de abastecimento de água potável ou de esgotamento sanitário, considerados os contratos regulares em vigor, com vistas a viabilizar o cumprimento das metas de universalização previstas no caput do art. 11-B da Lei $\mathrm{n}^{\circ}$ 11.445, de 2007. https://www.in.gov.br/web/dou/-/decreto-n-10.710-de-31-de-maio-de-2021-323171056

Diário Oficial da Paraíba (2021), Lei Complementar n. 168, de 22 de junho de 2021. Institui as Microrregiões de Águas e Esgoto do Alto Piranhas, do Espinharas, da Borborema e do Litoral e suas respectivas estruturas de governança. https://auniao.pb.gov.br/servicos/arquivo-digital/doe/2021/junho/diario-oficial-23-062021.pdf

Estudo Técnico [FUNDACE] (2021). Regionalização do Saneamento Básico: Paraíba. Microrregiões de Água e Esgoto da Paraíba. https://paraiba.pb.gov.br/diretas/secretaria-de-infraestrutura-dos-recursos-hidricos-e-do-meio-ambiente/arquivos/consulta-

publica/ESTUDOREGIONALIZAOPARABA.pdf

G1 (2017). Água da Transposição do Rio São Francisco Chega na Paraíba. http://g1.globo.com/pb/paraiba/noticia/2017/03/agua-da-transposicao-do-rio-saofrancisco-chega-paraiba-diz-mpf.html

Geo Portal da AESA (2020). Download do shapefile da situação das adutoras por municípios. http://geoserver.aesa.pb.gov.br/geoprocessamento/geoportal/shapes.html

Governo do Estado da Paraíba (2021). Anexo V da Lei Complementar n. 168. Perguntas - consulta e audiência públicas. https://paraiba.pb.gov.br/direta 
s/secretaria -de-infraestrutura-dos-recursos-hidricos-e-do-meio-ambiente/arquivos/consulta-publica/ANEXOVPERGUNTASRESPOND IDASCONSULTAEA UDINCIAPBLICA.pdf

Héller, L. (2020). Realização progressiva dos direitos humanos à água e ao esgotamento sanitário. Relatório do Relator Especial sobre os direitos humanos à água potável e ao esgotamento sanitário (ONU).

Kishimoto, S., Lobina, E. \& Petitjean, O. (2015). Our public water future: The global experience with remunicipalisation. https://www.tni.org/files/download/ourpublicwaterfuture-1.pdf

Kishimoto, Steinfort e Petitjean (2020). O Futuro é Público: pela Propriedade Democrática dos Serviços Públicos. pp. 275. https://www.tni.org/files/publication-downloads/o_futuro_e_publico_versao_digital_02122021-compactado.pdf

Koche, J. C. (2011). Fundamentos de metodologia científica. Petrópolis: Vozes.

Lei Complementar no 168 (2021), de 22 de junho de 2021. Institui as Microrregiões de Água e Esgoto do Alto Piranhas, do Espinharas, da Borborema e do Litoral e suas respectivas estruturas de governança. https://auniao.pb.gov.br/servicos/arquivo-digital/doe/2021/junho/diario-oficial-23-06-2021.pdf

Lei Federal n ${ }^{\circ} 10.768$ (2003), de 19 de novembro de 2003. Dispõe sobre o Quadro de Pessoal da Agência Nacional de Águas e Saneamento Básico (ANA) e dá outras providências. (Redação dada pela Lei nº 14.026, de 2020). http://www.planalto.gov.br/ccivil_03/Leis/2003/110.768.htm

Lei Federal n 9.984 (2000), de 17 de julho de 2000. Dispõe sobre a criação da Agência Nacional de Águas e Saneamento Básico (ANA), entidade federal de implementação da Política Nacional de Recursos Hídricos, integrante do Sistema Nacional de Gerenciamento de Recursos Hídricos (Singreh) e responsável pela instituição de normas de referência para a regulação dos serviços públicos de saneamento básico. http://www.planalto.gov.br/ccivil_03/leis/19984.htm

Lei Federal no 12.305 (2010), 02 de agosto de 2010. Institui a Política Nacional de Resíduos Sólidos; altera a Lei no 9.605 , de 12 de fevereiro de 1998; e dá outras providências. http://www.planalto.gov.br/ccivil_03/_ato2007-2010/2010/lei/112305.htm

Lei Federal $N^{\mathrm{o}} 12.527$ (2011), de 18 de novembro de 2011. Regula o acesso a informações previsto no inciso XXXIII do art. $5^{\circ}$, no inciso II do $§ 3^{\circ}$ do art. 37 e no $\S 2^{\circ}$ do art. 216 da Constituição Federal; altera a Lei $n^{\circ} 8.112$, de 11 de dezembro de 1990; revoga a Lei $\mathrm{n}^{\circ} 11.111$, de 5 de maio de 2005 , e dispositivos da Lei $\mathrm{n}^{\circ}$ 8.159, de 8 de janeiro de 1991; e dá outras providências. http://www.planalto.gov.br/ccivil_03/_ato2011-2014/2011/lei/112527.htm

Lei Federal no 13.089 (2015), de 12 de janeiro de 2015. Institui o Estatuto da Metrópole, altera a Lei nº 10.257, de 10 de julho de 2001 , e dá outras providências. http://www.planalto.gov.br/ccivil_03/_ato2015-2018/2015/lei/113089.htm

Lei Federal no 13.529 (2017), de 04 de dezembro de 2017. Dispõe sobre a participação da União em fundo de apoio à estruturação e ao desenvolvimento de projetos de concessões e parcerias público-privadas; altera a Lei n ${ }^{\circ} 11.079$, de 30 de dezembro de 2004, que institui normas gerais para licitação e contratação de parceria público-privada na administração pública, a Lei $n^{\circ} 11.578$, de 26 de novembro de 2007, que dispõe sobre a transferência obrigatória de recursos financeiros para a execução pelos Estados, Distrito Federal e Municípios de ações do Programa de Aceleração do Crescimento (PAC), e a Lei ${ }^{\circ}$ 12.712, de 30 de agosto de 2012, que autoriza o Poder Executivo a criar a Agência Brasileira Gestora de Fundos Garantidores e Garantias S.A. (ABGF). http://www.planalto.gov.br/ccivil_03/_ato2015-2018/2017/lei/113529.htm

Lei Federal $n^{\circ} 14.026$ (2020), de 15 de julho de 2020. Atualiza o marco legal do saneamento básico e altera a Lei ${ }^{\circ} 9.984$, de 17 de julho de 2000 , para atribuir à Agência Nacional de Águas e Saneamento Básico (ANA) competência para editar normas de referência sobre o serviço de saneamento, a Lei no 10.768 , de 19 de novembro de 2003, para alterar o nome e as atribuições do cargo de Especialista em Recursos Hídricos, a Lei n 11.107 , de 6 de abril de 2005, para vedar a prestação por contrato de programa dos serviços públicos de que trata o art. 175 da Constituição Federal, a Lei nº 11.445 , de 5 de janeiro de 2007, para aprimorar as condições estruturais do saneamento básico no País, a Lei $\mathrm{n}^{\circ} \mathbf{1 2 . 3 0 5}$, de 2 de agosto de 2010, para tratar dos prazos para a disposição final ambientalmente adequada dos rejeitos, a Lei ${ }^{\circ} 13.089$, de 12 de janeiro de 2015 (Estatuto da Metrópole), para estender seu âmbito de aplicação às microrregiões, e a Lei ${ }^{\circ}$ 13.529, de 4 de dezembro de 2017, para autorizar a União a participar de fundo com a finalidade exclusiva de financiar serviços técnicos especializados. http://www.planalto.gov.br/ccivil_03/_ato2019-2022/2020/lei/114026.htm

Lei n. 11.445, de 05 de janeiro de 2007. Estabelece diretrizes nacionais para o saneamento básico; cria o Comitê Interministerial de Saneamento Básico; altera as Leis n. 6.766, de 19 de dezembro de 1979, 8.666, de 21 de junho de 1993, e 8.987, de 13 de fevereiro de 1995; e revoga a Lei n. 6.528, de 11 de maio de 1978. http://www.planalto.gov.br/ccivil_03/_ato2007-2010/2007/lei/111445.htm.

Pereira A. S. et al. (2018). Metodologia da pesquisa científica. UFSM

Projeto de Lei Complementar (2021a), de 30 de maio de 2021. Institui as Microrregiões de Águas e Esgoto do Alto Piranhas, do Espinharas, da Borborema e do Litoral e suas respectivas estruturas de governança. https://paraiba.pb.gov.br/diretas/secretaria-de-infraestrutura-dos-recursos-hidricos-e-do-meioambiente/arquivos/consulta-publica/minuta-de-lei-complementar-microrregioes-paraiba.pdf

Projeto de Lei Complementar (2021b), de 14 de junho de 2021. Institui as Microrregiões de Águas e Esgoto do Alto Piranhas, do Espinharas, da Borborema e do Litoral e suas respectivas estruturas de governança. https://paraiba.pb.gov.br/diretas/secretaria-de-infraestrutura-dos-recursos-hidricos-e-do-meioambiente/arquivos/consulta-publica/ANEXOVIMINUTADELEICOMPLEMENTAR.pdf

Relatório de Impacto Ambiental [RIMA] (2004). https://antigo.mdr.gov.br/images/stories/ProjetoRioSaoFrancisco/Ar quivosPDF/d ocumentostecnicos/RIMAJULHO2004.pdf

Salles, M. J (2009). Política nacional de saneamento: percorrendo caminhos em busca da universalização. Tese (Saúde Pública) - Escola Nacional de Saúde Pública Sergio. pp. 176

Secretaria Nacional de Saneamento - SNS (2020). https://www.gov.br/mdr/pt-br/assuntos/saneamento/secretaria-nacional-de-saneamento

SEIRHMA PB (2021). Audiência Pública: Proposta de Regionalização - Microrregiões de Água e Esgotos https://www.youtube.com/watch?v= IcMkjFQp3jQ\&t=5573s

Sistema Nacional de Informações sobre Saneamento (2018). Glossário de Indicadores - Água e Esgotos. http://www.snis.gov.br/glossarios 
Research, Society and Development, v. 10, n. 10, e117101018513, 2021

(CC BY 4.0) | ISSN 2525-3409 | DOI: http://dx.doi.org/10.33448/rsd-v10i10.18513

Sistema Nacional de Informações sobre Saneamento (2021). Download de dados do Saneamento na Paraíba (2015, 2017 e 2019). http://app4.mdr.gov.br/serieHistorica/

SNIS (2018). Diagnóstico de Água e Esgoto. http://www.snis.gov.br/downloads/diagnosticos/ae/2018/Diagnostico_AE2018.pdf

SNIS (2019). Diagnóstico de Água e Esgoto. http://www.snis.gov.br/downloads/diagnosticos/ae/2019/Diagnostico-SNIS-AE-2019-Capitulo-11.pdf

TV ASSEMBLEIA PB (2021a). Reunião da comissão de desenvolvimento, turismo e meio ambiente (15 de junho de 2021). Recuperado em https://www.youtube.com/watch?v=-JwcW9c6IYM

TV ASSEMBLEIA PB (2021b). 26 ${ }^{a}$ Sessão Ordinária. https://www.youtube.com/watch?v=aOlqA9sxZCY\&t=749s

Yin, R.K. (2015). O estudo de caso. Bookman. 